\title{
ЗОНАЛЬНОСТЬ ПО МАКРО- И МИКРОЭЛЕМЕНТАМ \\ В ПЛАГИОКЛАЗЕ ВУЛКАНА КИЗИМЕН (КАМЧАТКА) ПРИМЕНИТЕЛЬНО К ПРОЦЕССАМ В МАГМАТИЧЕСКОМ ОЧАГЕ
}

\author{
(C) 2013 г. Т. Г. Чурикова 1,2 , Б. В. Иванов ${ }^{1}$, Дж. Айкельбергер ${ }^{3}$, \\ Г. Вёрнер ${ }^{2}$, Б. Броун ${ }^{4}$, П. Избеков 5 \\ ${ }^{1}$ Институт вулканологии и сейсмологии ДВО РАН \\ 683006 Петропавловск-Камчатский, б-р Пийпа, 9, \\ e-mail: tchurikova@mail.ru \\ ${ }^{2}$ Отделение геохимии Центра геологических наук Геттингенского университета \\ Германия, 37077 Геттинген, ул. Гольдшмидта, 1, \\ e-mail: gwoerne@gwdg.de \\ ${ }^{3}$ Программа вулканической опасности Геологической службы США \\ Рестон, Вирджиния, США, \\ e-mail: jeichelberger@usgs.gov \\ ${ }^{4}$ Отделение геологических наук Калифорнийского государственного университета \\ Фуллертон, Калифорния, США, \\ e-mail: bbrowne@fullerton.edu \\ ${ }^{5}$ Вулканологическая обсерватория Геофизического института Университета \\ Аляски Фэрбенкс, Аляска, США, \\ e-mail:pavel@gi.alaska.edu \\ Поступила в редакцию 25.10.2010 г.
}

\begin{abstract}
Представлены данные по геохимии пород вулкана Кизимен и результаты микрозондовых исследований зерен плагиоклаза из кислых лав и базальтовых включений на макро- и микроэлементы. Вулкан Кизимен характеризуется следующими особенностями: 1) кислые лавы насыщены базальтовыми включениями; 2) распространены полосчатые, смешанные лавы; 3) кривые распределения редкоземельных элементов кислых лав и базальтовых включений пересекаются; 4) Sr-Nd изотопная систематика пород и включений не указывает на смешение с коровым материалом; 5) фенокристаллы плагиоклаза имеют как прямую, так и обратную зональность; 6) в породах сосуществуют оливин и роговая обманка, а также основной и кислый плагиоклазы. Исследования показали, что породы вулкана являются гибридными и сформировались в результате неоднократного смешения кислых и основных расплавов, причем наблюдается как химическое и тепловое взаимодействие расплавов, так и исключительно тепловое. Изучение распределения макро- и микроэлементов в зональных минералах является информативным инструментом для понимания истории формирования и эволюции расплавов в магматическом очаге.
\end{abstract}

DOI: $10.7868 / \mathrm{S} 0203030613020028$

\section{ВВЕДЕНИЕ}

Процессы, протекающие в магматических очагах, такие, как конвекция и смешение магм, дифференциация расплавов, рост кристаллов в расплаве, играют важную роль в формировании магматических пород. Экспериментальные и расчетные модели этих процессов, например, [Marsh, 1989], дают возможность изучать такие физические параметры, как плотность и вязкость в зависимости от состава расплава, температурных градиентов внутри очага и на его контакте с вмещающей породой, геометрии очага и т.д. Поскольку часть перечисленных параметров в ре- альных природных системах не поддаются однозначному определению, применимость таких моделей ограничена.

Процесс смешения магм, предложенный Р. Бунзеном в 1851 г. [Bunsen, 1851], до последнего времени изучается активно, и в настоящее время роль этого процесса при формировании изверженных горных пород не может быть недооценена. Особенно часто случаи смешения частичнозакристаллизованных магм проявлены в островодужных обстановках, где внутри долгоживущих магматических очагов магма имеет возможность фракционировать до кислых разностей. При этом 
помимо случаев смешения различных по составу и происхождению магм, часто наблюдается смешение магм одинакового происхождения, которые обособились в результате дифференциации, ассимиляции или отделения порций магмы в приповерхностные очаги [Kawamoto, 1992; Наyмов и др., 1997; Couch et al., 2001]. В этом случае более глубинные магмы основного (базальтового) состава периодически поступают в близповерхностные коровые очаги, содержащие кислую магму, в результате чего формируется ряд гибридных смешанных магм [Иванов и др., 1978; Eichelberger et al., 1978].

В зависимости от степени смешения, изверженные гибридные лавы могут быть представлены полосчатыми лавами, либо крупными обособленными блоками основной лавы внутри потока кислой лавы, либо относительно однородной лавой, содержащей, тем не менее, явно неравновесные с основной массой вкрапленники. При микроскопическом исследовании пород процесс смешения магм также имеет ряд характерных признаков: это резорбция вкрапленников, формирование реакционной каймы и обратная зональность минералов в связи с растворением низкотемпературных минералов при повышении температуры расплава и последующего роста кристаллов из нового гибридного расплава, а также наличие неравновесных ассоциаций вкрапленников [Dungan, Rhodes, 1978; Кадик и др., 1986; Eichelberger et al., 2000, 2006; Плечов и др., 2008].

В последнее время многие исследователи изучают геохимическую зональность в плагиоклазах, пироксенах и других минералах, рассматривая ее как индикатор изменчивости среды роста минерала, позволяющей проследить историю кристаллизации минералов в породах вулканических извержений. Плагиоклазы, имеющие зачастую многоуровневую зональность, легко реагируют на изменения состава магмы или условий ее кристаллизации [Волынец и др., 1979; Фрих-Хар, 1977; Davidson, Tepley III, 1997; Ginibre et al., 2002a, 2002b]. Зональность плагиоклазов по главным элементам, отражающая диффузию $\mathrm{CaAl}-\mathrm{NaSi}$ пар в плагиоклазовой An-Ab двойной системе [Grove et al., 1984; Tsuchiyama, 1985], широко использовалась при изучении процессов в магматическом очаге. Во многих расчетных моделях, в т.ч. [Allègre et al., 1981], также делались попытки оценить кинетические аспекты роста кристаллов плагиоклаза и их резорбции.

Все эти исследования помогают лучше понять причину возникновения зональности в плагиоклазах. Тем не менее, до последнего времени совместное влияние нескольких факторов, таких как температура, давление, состав расплава, содержание $\mathrm{H}_{2} \mathrm{O}$ на систему An-Ab было трудно различимо.
Благодаря развитию локальных высокоточных методов анализа вещества, использующих электронный микроанализатор и ионный зонд, появилась возможность анализировать не только малые элементы, которые, как правило, замещают макроэлементы в структуре минерала и присутствуют в концентрациях $0.1-1.0$ вес. \%, но и редкие элементы, которые обычно находятся в пустотах кристаллических решеток минералов, и их концентрации не превышают 0.1 вес. \% [Winter, 2001]. Кроме того, в последние годы появляется все больше работ по определению изотопных отношений в отдельных зонах кристаллов плагиоклаза на площадке в несколько микрон с использованием ионного зонда [Brophy et al., 1996] или изотопных масс-спектрометров [Чурикова, Соколов, 1993; Davidson, Tepley III, 1997; Tepley III, Davidson, 2000]. Эти методы значительно улучшили возможность идентификации различных причин зональности плагиоклазов, в т.ч. смешения магм разного состава, ассимиляции, влияния температурного фактора. Однако, эти методы очень трудоемки и дороги, а в случае ионного зонда часть кристалла полностью выгорает, из-за чего не всегда можно провести повторное измерение. Современные электронные микроанализаторы позволяют определять ряд микроэлементов в концентрациях до 100 ppm в отдельных зонах плагиоклаза на площадке размером в несколько микрон [Ginibre et al., 2002a, 2002b]. Эти приборы дают возможность исследовать как на макро-, так и на микроэлементы большое количество образцов, не разрушая исследуемого материала.

В настоящей работе приводятся результаты анализа фенокристаллов плагиоклаза из базальтов, андезибазальтов и дацитов вулкана Кизимен, полученные с использованием современного электронного микроанализатора. Детальные тефрохронологические исследования [Мелекесцев и др., 1992] возраста лавовых потоков и эруптивной истории вулкана показали, что он сформирован в четвертичное время и был активен в течение голоцена (наиболее поздние лавы датируются поздним голоценом). В настоящее время на склоне вулкана наблюдается активная фумарольная деятельность.

Исследование пород вулкана проходило в два этапа. На первом были изучены содержания макро- и микроэлементов, а также изотопные отношения $\mathrm{Sr}, \mathrm{Nd}$ и $\mathrm{Pb}$ в породах вулкана; на втором исследованы кристаллы плагиоклаза в наиболее представительных образцах. Электронный микроскоп был использован для определения содержаний макро- (Al, $\mathrm{Si}, \mathrm{Na}, \mathrm{Ca}, \mathrm{K})$ и микроэлементов ( $\mathrm{Ba}, \mathrm{Sr}, \mathrm{Mg}, \mathrm{Fe})$ в отдельных точках размером в несколько микрон. Выбор положения точек для измерений делался по снимкам высокого разрешения в отраженном свете. Исследования были направлены как на изучение магматической эво- 
люции вулкана, так и на выявление процессов, влияющих на кристаллизацию расплава внутри магматического очага до извержения.

\section{1. МЕТОДЫ ИССЛЕДОВАНИЯ}

Все аналитические работы производились в Отделении геохимии Центра геологических наук Гёттингенского университета (Германия). Содержания в породах макроэлементов и некоторых микроэлементов ( $\mathrm{Sc}, \mathrm{V}, \mathrm{Cr}, \mathrm{Co}, \mathrm{Ni}, \mathrm{Zn}, \mathrm{Ga}, \mathrm{Sr}, \mathrm{Zr}, \mathrm{Ba}$ ) определялись рентгенофлуоресцентным анализом (РФА). Относительные аналитические ошибки $( \pm 2 \delta)$ для макроэлементов составили менее $1 \%$ (за исключением $\mathrm{Fe}, \mathrm{Na}-2 \%$ ) и для микроэлементов около 5\%. Ошибка определения потерь при прокаливании 10\%. Все остальные редкие элементы определялись методом ICPMS. Ошибки, оцененные по стандартам JB3 и JА2, составляют для $\mathrm{Nb}$ и Та около 15-20\%, для других редких элементов - менее $10 \%$.

Изотопные отношения $\mathrm{Sr}, \mathrm{Nd}$ и $\mathrm{Pb}$ измерялись на масс-спектрометре Finnigan MAT 262 RPQ II+ c использованием стандарта NBS987 (0.710245) для $\mathrm{Sr}$, стандарта La Jolla (0.511847) для Nd и стандарта NBS981 (рекомендованные значения по [Todt et al., 1984]) для $\mathrm{Pb}$. Статистические ошибки $( \pm 2 \sigma)$ составили менее $0.004 \%$ для $\mathrm{Sr}$ и $\mathrm{Nd}$ и менее $0.1 \%$ для $\mathrm{Pb}$. Детальное описание всех методик можно найти в работах [Чурикова и др., 2001; Churikova et al., 2001, 2007; Dorendorf et al., 2000a, 2000b].

Содержания макроэлементов ( $\mathrm{Si}, \mathrm{Al}, \mathrm{Ca}, \mathrm{Na}$ и $\mathrm{K})$ и микроэлементов ( $\mathrm{Mg}, \mathrm{Fe}, \mathrm{Ti}, \mathrm{Ba}$ и $\mathrm{Sr})$ в плагиоклазах определялись на электронном микроанализаторе JEOL8900 WDS с использованием набора синтетических и природных стандартов. Отдельные зоны в кристаллах плагиоклаза идентифицировались по изображениям кристаллов в отраженных электронах. Для выяснения эволюции плагиоклазов в процессе их роста химический анализ выполнялся по профилям от центров вкрапленников к их каймам, при этом анализировались разные зоны и участки неоднородностей в кристаллах. Для сравнения в тех же образцах анализировались центральные и краевые части микролитов.

Методика определения макро- и микроэлементов на приборе JEOL8900 WDS детально описана в работах [Ginibre et al., 2002a, 2002b]. Количественный анализ в точке на $\mathrm{Al}, \mathrm{Si}, \mathrm{Na}, \mathrm{Ca}, \mathrm{K}, \mathrm{Ba}$, $\mathrm{Sr}, \mathrm{Fe}, \mathrm{Ti}$ и $\mathrm{Mg}$ производился при ускоряющем напряжении в $20 \mathrm{kV}$ при токе пучка 40 nA и области зоны возбуждения от 2 до 5 микрон. Сначала мы анализировали щелочные элементы и все макроэлементы ( $\mathrm{Na}, \mathrm{K}, \mathrm{Al}, \mathrm{Si}, \mathrm{Ca})$ в течение первых 90 сек (время измерения на пике 16 сек). Следом анализировались малые ( $\mathrm{Sr}$ и $\mathrm{Fe}$ ) и редкие элементы (Ti, Mg, Ba), время для которых было уве- личено до 4 и более минут на пике каждого элемента.

\section{2. ГЕОЛОГИЧЕСКОЕ ПОЛОЖЕНИЕ, ПЕТРОГРАФИЯ И МИНЕРАЛОГИЯ ПОРОД}

Вулкан Кизимен (высота 2485 м; координаты 5508.0' с.ш., $160^{\circ} 19.3^{\prime}$ в.д.), один из активных голоценовых вулканов Камчатки, расположен на юго-восточном борту Щапинского грабена [Иванов, 2008], занимая граничное положение между двумя вулканически активными поясами: Центральной Камчатской Депрессией (ЦКД) и Восточным Вулканическим Фронтом (ВВФ). Северо-западная часть постройки вулкана срезана разломами, ориентированными СВ-Ю3, а также серией оврагов, в которых обнажаются породы основания стратовулкана. О единственном историческом извержении вулкана известно по сообщениям охотников, которые в 1928 г. отмечали появление огненных струй и черного дыма в районе Кизимена. Однако, судя по тому, что отложения близкого возраста у подножия вулкана отсутствуют, это извержение было довольно слабым.

Вулкан представляет собой сложный комплекс, сформированный многочисленными лавовыми потоками и экструзивными куполами (рис. 1). Согласно детальным тефрохронологическим исследованиям, возраст пород варьирует от 12-11 тыс. л.н. до 1 тыс. л.н. [Мелекесцев и др., 1992].

Продукты извержения вулкана Кизимен преимущественно андезитового и дацитового состава слагают многочисленные лавовые потоки и серию экструзивных куполов, сосредоточеных в привершинной части вулкана. Андезитовые и дацитовые потоки насыщены сингенетичными включениями более основного, базальтового и андезибазальтового состава (рис. 2a). Далее, для краткости, под базальтовым включением будет иметься в виду базальтовое или андезибазальтовое включение. В наиболее молодых привершинных лавах количество таких включений достигает $35 \%$ объема лавового потока. Довольно часто можно наблюдать, что дацитовые лавы выносят включения андезибазальтов, которые, в свою очередь, содержат базальтовые включения (см. рис. 2б). Часто встречаются полосчатые лавы, размер полос в которых варьирует от первых мм до 20-25 см (см. рис. 2в).

По размеру минералов-вкрапленников породы вулкана средне-крупно-кристаллические, часто серийнопорфировые. По химическому составу они представлены рядом от базальтов до дацитов (рис. 3, табл.). При этом состав лав изменяется от андезибазальтов до дацитов, в то время как темноцветные включения в них всегда имеют более основной состав и соответствуют базальтам, реже андезибазальтам. 


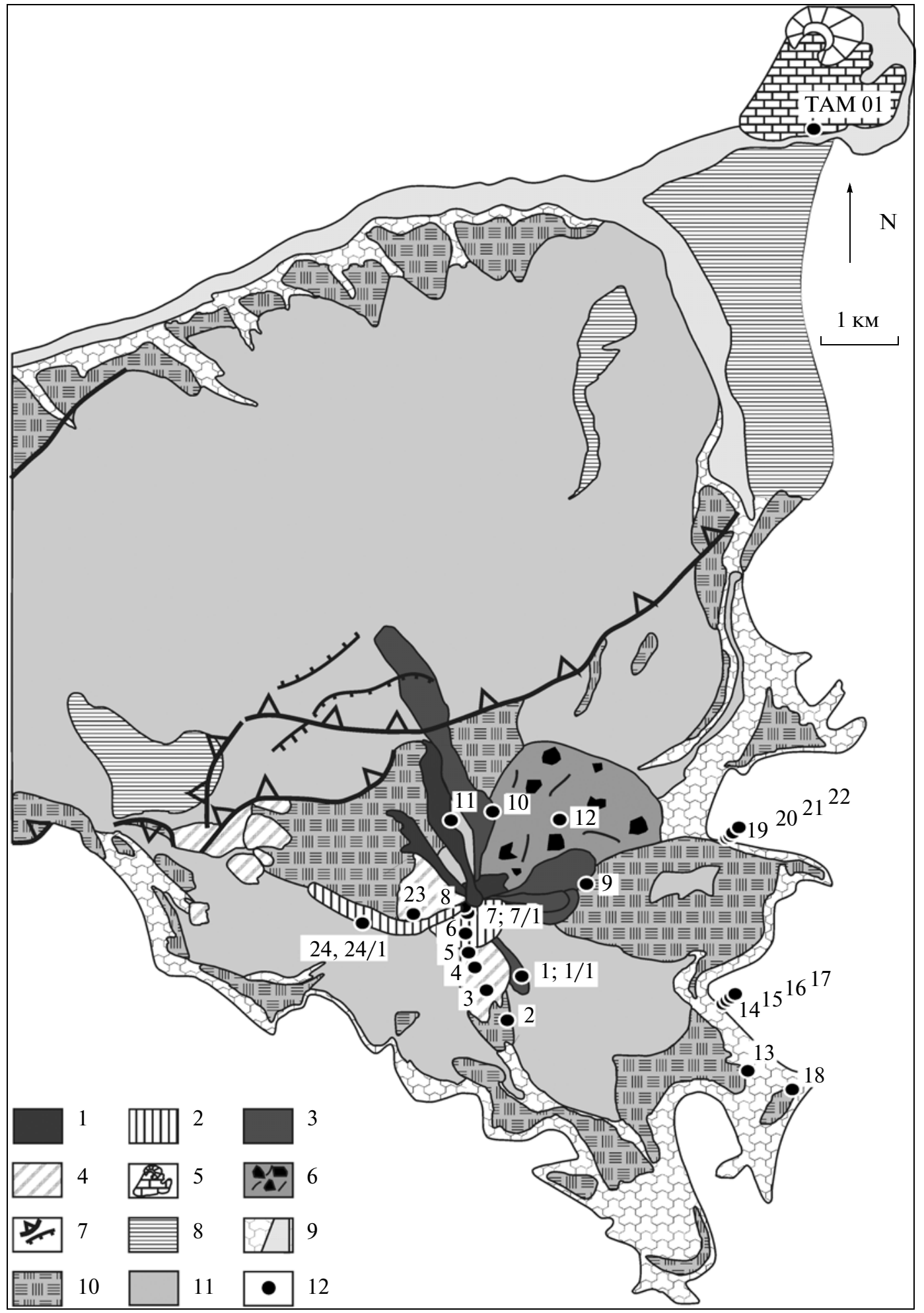

Рис. 1. Схема вулкана Кизимен, по [Мелекесцев и др., 1992].

Лавовые потоки и экструзивные купола: 1 - моложе 1100 л.н., 2 - возраста 3000-1200 л.н.; 3 - лавовые потоки возраста 1200 и 1700 л.н.; 4 - лавовые потоки и экструзивные купола возраста 7700 и 11000 л.н.; 5 - конус Тамара позднеплейстоценового возраста; 6 - пирокластические потоки и обвалы моложе 3000 л.н.; 7 - сбросы различной амплитуды; 8 - ледниковые отложения; 9 - аллювиальные осадки; 10 - пирокластические потоки и обвалы возраста 11000-8400 л.н.; 11 пирокластические потоки и обвалы возраста 8400-3000 л.н.; 12 - точки геохимического опробования KIZ-96-** и TAM-96-01. 

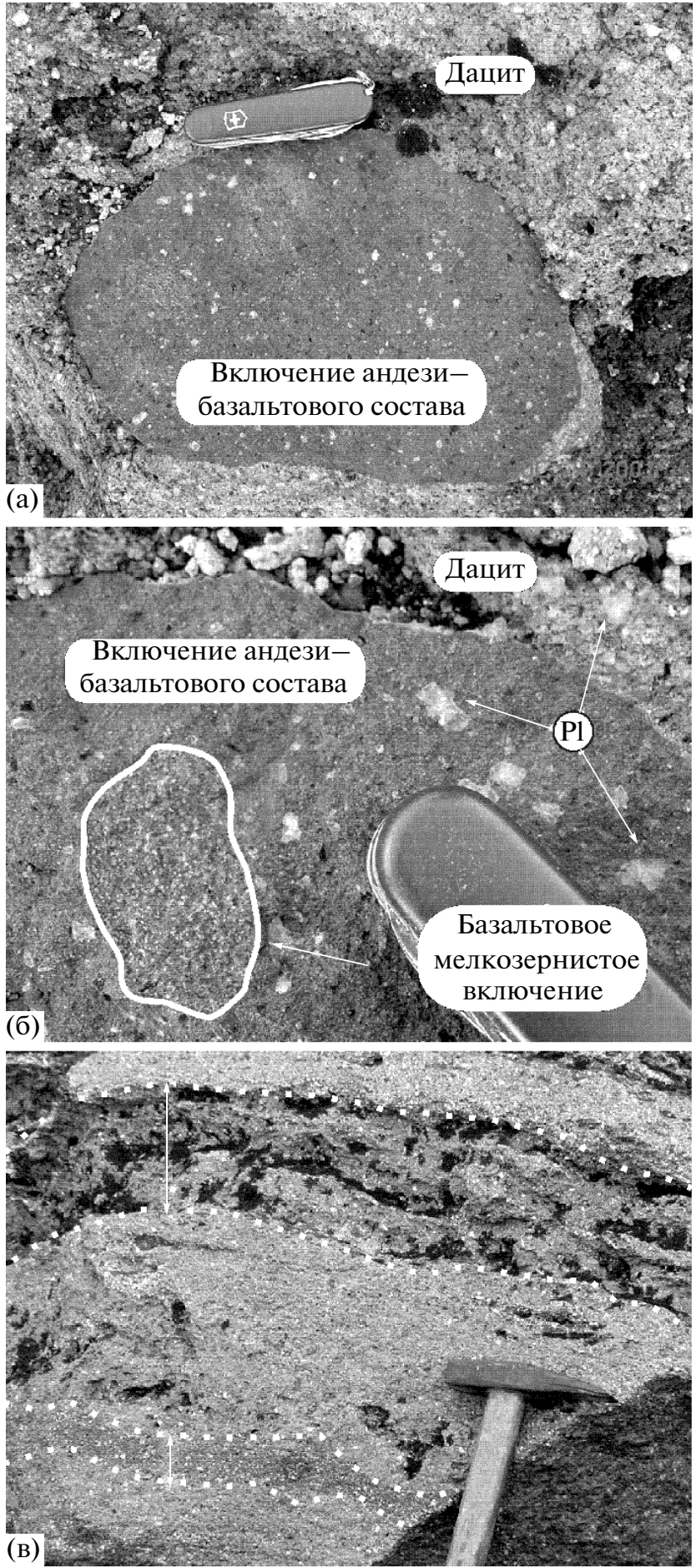

Рис. 2. Лавы вулкана Кизимен и включения основного состава в них.

Крупное включение $17 \times 20$ см андезибазальта в дацитовой лаве (a); мелкозернистое включение базальтового состава размером $3 \times 5$ см (отмечено сплошной белой линией) внутри более крупного андезибазальтового включения (б), показанного на (а), крупные фенокристаллы плагиоклаза в андезито-базальте и в даците показаны стрелками; фрагмент полосчатой лавы (в), темноцветные полоски выделены белыми точечными линиями, их мощности указаны двойными стрелками.
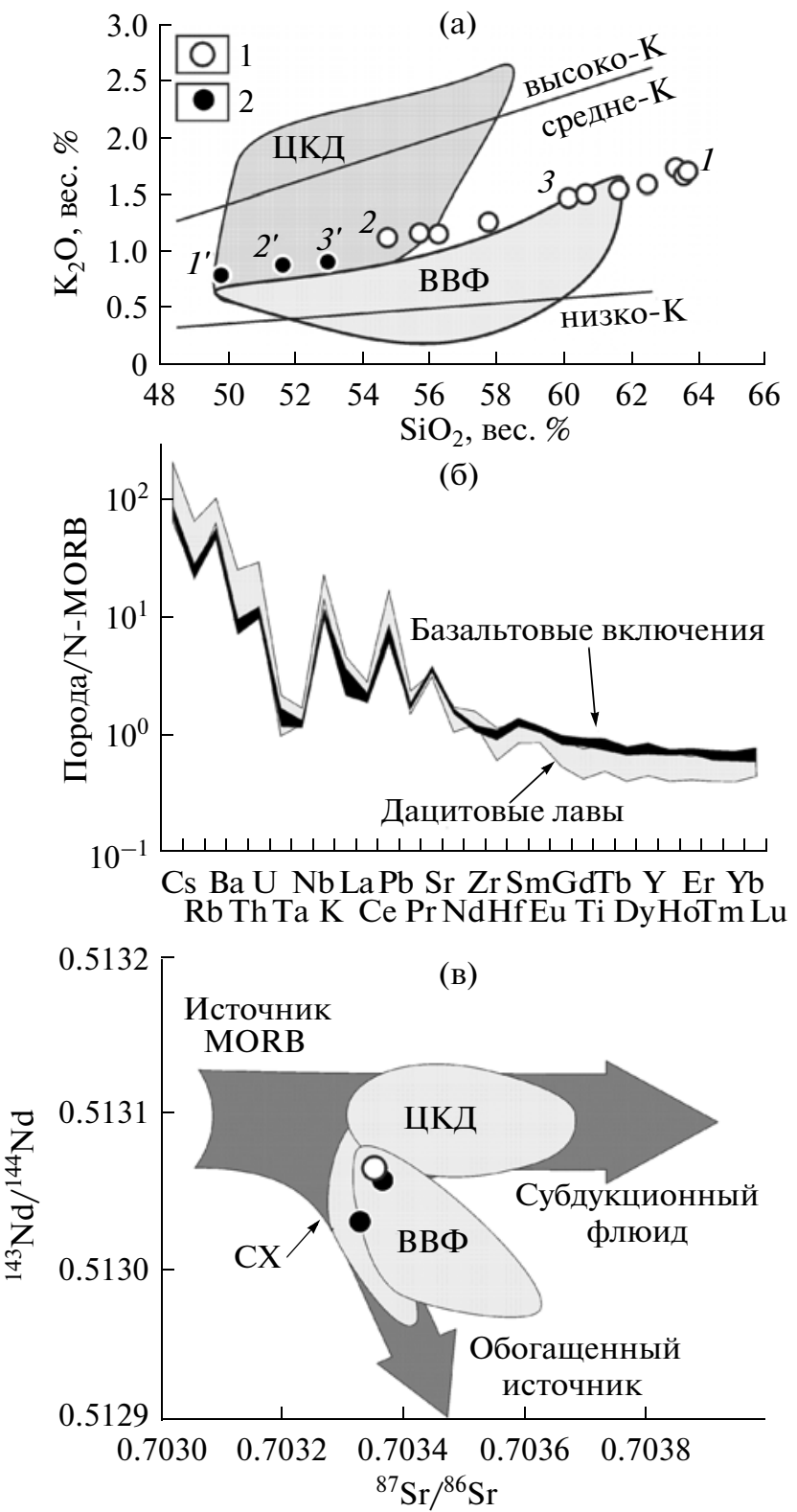

Рис. 3. Геохимические особенности пород вулкана Кизимен.

1 - лавы; 2 - включения основного состава в лавах. Диаграмма $\mathrm{K}_{2} \mathrm{O}-\mathrm{SiO}_{2}$ для пород вулкана Кизимен (а). Породы ВВФ и ЦКД показаны серыми полями по данным [Churikova et al., 2001]. Парными цифровыми обозначениями $(1-1)$ показаны пары пород (вмешающая лава и включение, соответственно) для трех отдельных извержений: $1-1^{\prime}-1600$ л.н., $2-2^{\prime}-$ 2700 л.н., 3 - 3'- 3000 л.н. [Мелекесцев и др., 1992].

Диаграммы распределения малых элементов в породах вулкана Кизимен (б): серое поле - в лавах вулкана, черное поле - во включениях основного состава. Данные нормализованы к значениям NMORB, по [Sun, McDonough, 1989].

Изотопные отношения в породах вулкана Кизимен (в). Стрелки схематически указывают положение трех источников вещества в породах Камчатки: источника типа MORB, субдукционного флюида и обогащенного источника типа ОІВ. Серым цветом выделены поля пород ВВФ, ЦКД и СХ по данным [Churikova et al., 2001; Dorendorf et al., 2000b]. 
Характерной особенностью пород является сосуществование в них крупных фенокристаллов плагиоклаза (до 2 см), роговой обманки, оливина и ортопироксена. Все породы содержат роговую обманку, относятся к умеренно-калиевой известково-щелочной серии и формируют узкий тренд фракционирования (см. рис. 3a), при этом как базальты, так и вмещающие их дациты, формируют единые тренды на различных дискриминационных диаграммах. Установлено, что состав базальтовых включений в дацитах становится более мафическим в поздних лавах (см. рис. За), что позволяет предположить антидромную историю развития вулкана. Вулкан Кизимен не только пространственно находится между ВВФ и ЦКД, но и, как видно на рис. 3а, породы вулкана обогащены калием в сравнении с лавами ВВФ, но обеднены им по сравнению с породами ЦКД, занимая, таким образом, промежуточное положение между полями фигуративных точек пород двух вулканических поясов Камчатки.

\section{3. ГЕОХИМИЧЕСКИЕ ОСОБЕННОСТИ ПОРОД}

Распределение малых и редких элементов пород вулкана на спайдер-диаграммах (см. рис. 3б) является типичным для островодужных серий с характерным для них обогащением литофильными крупно-ионными элементами (LILE: K, Cs, U, $\mathrm{Ba}, \mathrm{Rb}, \mathrm{Sr}$ и $\mathrm{Pb}$ ) и обеднением высоко-зарядными (HFSE: Nb, Ta, Hf, Zr, Ti) и редкоземельными (REE) элементами. Вместе с тем, андезиты и дациты обогащены LILE и легкими редкоземельными элементами (LREE: La-Sm) и обеднены тяжелыми редкоземельными элементами (HREE: $\mathrm{Eu}-\mathrm{Lu})$ по сравнению с базальтами и андезибазальтами включений, формируя пересечение кривых распределения элементов на спайдердиаграммах для кислых и основных разностей пород (см. рис. 3б).

Наблюдаемое пересечение кривых на спайдердиаграммах можно было бы объяснить тем, что основные и кислые породы были образованы из разных источников. Спайдер-диаграммы пород, кристаллизовавшихся из одного, в разной степени фракционированного расплава, являются, как правило, субпараллельными, причем более кислые разности обогащены по сравнению с основными разностями всеми редкими элементами. Так происходит до тех пор, пока из расплава кристаллизуются такие минералы, как оливин, пироксены, плагиоклаз и шпинель (или магнетит). Эти минералы содержат крайне небольшие количества малых элементов, благодаря чему последние остаются в расплаве, накапливаясь в его более поздних порциях. Когда же из расплава начинает фракционировать роговая обманка, то происходит обеднение дацитовых разностей тяжелыми редко- земельными элементами, и линии распределения редкоземельных элементов дацитовых и основных пород могут пересечься. Подобное пересечение линий распределения редкоземельных элементов было установлено и численно смоделировано Ф. Дорендорфом с соавторами [Dorendorf et al., 2000a] для пород вулкана Бакенинг. Исходя из этих результатов, мы заключаем, что пересечение кривых распределения микроэлементов на спайдер-диаграммах пород вулкана Кизимен возникает благодаря активной кристаллизации амфибола и указывает на то, что как базальтовые включения, так и вмещающие их дациты формировались либо из одного, либо из разных, но близких по составу мантийных расплавов. Об активной кристаллизация амфибола свидетельствует тот факт, что все породы вулкана, как кислые вмещающие разности, так и основные включения, систематически содержат роговую обманку.

Согласно петрографическим и геохимическим характеристикам $\left(\mathrm{Fo}_{72-78}\right.$, низкие значения $\mathrm{Mg \#}$ пород - 41-50, насыщенность пород плагиоклазом и амфиболом), базальтовые и андезибазальтовые включения Кизимена в свою очередь также фракционированы в сравнении с примитивными мантийными расплавами и в различной степени контаминированы более кислым материалом вмещающей лавы. В то же время дацитовые и андезитовые лавы контаминированы более основным материалом включений. На процессы смешения базальтового и дацитового материала указывает присутствие так называемых полосчатых лав, где полоски варьируют от десятков сантиметров до почти неразличимых смешанных узоров. Наличие многочисленных включений базальтов внутри андезибазальтовых включений, границы которых часто размыты (см. рис. 2a), также указывает на то, что расплавы разного состава смешивались неоднократно. Таким образом, как кислые лавы, так и основные включения в них являются гибридными и сформированы при смешении более экстремальных конечных членов, которые, сами не представлены среди пород вулкана. На фоне региональных геохимических вариаций пород Камчатки от фронта к тылу дуги с изменениями щелочности более чем в 4 раза и содержаний большинства некогерентных элементов в 2-4 раза [Иванов, 2008; Пономарева и др., 2008; Churikova et al., 2001] лавы вулкана Кизимен занимают промежуточное положение между вулканитами ВВФ и ЦКД не только по макро- (см. рис. 3а), но и по всем микроэлементам.

$\mathrm{Sr}$ и $\mathrm{Nd}$ изотопные отношения в трех наиболее основных породах вулкана крайне близки (см. рис. 3в) и варьируют незначительно $\left({ }^{87} \mathrm{Sr} /{ }^{86} \mathrm{Sr}\right.$ : $\left.0.703352-0.703370,{ }^{143} \mathrm{Nd} /{ }^{144} \mathrm{Nd}: 0.513045-0.513048\right)$. Фигуративные точки базальтов вулкана Кизимен лежат внутри единого поля пород ВВФ, ЦКД и Сре- 
динного хребта (CX) Камчатки [Пономарева и др., 2008; Churikova et al., 2001] и являются по этим параметрам наиболее примитивными.

Таким образом, для пород вулкана Кизимен характерны следующие особенности: 1) лавовые потоки дацитового и андезитового состава содержат большое количество базальтовых и андезибазальтовых включений; 2) характерно обилие полосчатых, смешанных лав; 3) кривые распределения редкоземельных элементов дацитовых лав вулкана и базальтовых включений в них, пересекаются; 4) $\mathrm{Sr}-\mathrm{Nd}$ изотопная систематика пород и включений в них не предполагает контаминацию коровым материалом.

\section{4. РЕЗУЛЬТАТЫ ГЕОХИМИЧЕСКОГО АНАЛИЗА ПЛАГИОКЛАЗОВ}

Детальное изучение фенокристаллов плагиоклаза проводилось в трех образцах: а) дацитовая лава одного из привершинных потоков (образец № $\left.\mathrm{KIZ}-07, \mathrm{SiO}_{2}=60.1\right)$; б) андезибазальтовое включение в этой лаве (образец № KIZ-07/1, $\left.\mathrm{SiO}_{2}=52.9\right)$; в) базальтовое включение из другого привершинного потока (образец № KIZ-01/1, $\left.\mathrm{SiO}_{2}=49.7\right)$. Как во вмещающей породе, так и в базальтовых включениях фенокристаллы P1 представлены двумя генерациями: Pl-1 - нерезорбированные зерна с четкими очертаниями контуров и хорошо выраженными зонами роста (рис. 4a, 5a) и Pl-2 - в разной степени резорбированные фенокристаллы, в которых зоны резорбции иногда занимают более $50 \%$ кристалла (см. рис. 4б, 5б). При этом, как видно в отраженном свете, в нерезорбированных кристаллах из основных включений зональность практически отсутствует (см. рис. 4a), в то время как нерезорбированные зерна в лавах обладают тонкой зональностью, имеют зоны частичного растворения и залечивания (см. рис. 5а). Внутренняя часть резорбированных кристаллов, как в дацитах, так и во включениях, многозональна и близка по петрографическим особенностям к нерезорбированным кристаллам дацитовых лав.

Анализировалось несколько кристаллов каждой разновидности плагиоклазов из пар “кислая вмещающая лава - основное включение" на макpo- (Al, Si, Na, Ca, K) и микро- (Ba, Sr, Mg, Fe, Ti) элементы в точках размерами от 2 до 5 микрон по профилям от центра к краю фенокристаллов. Результаты анализа приведены в [Churikova et al., 2007] и показаны для четырех представительных зерен на рис. 4 и 5. Нерезорбированные фенокристаллы плагиоклазов (P1-1) из дацитовых лав и из основных включений в них принципиально различны по составу, в то время как резорбированные разности (Pl-2) удивительно схожи по химическому составу во всех изученных породах.

\section{1. Генерация кристаллов Pl-1 в базальтовых включениях}

Нерезорбированные кристаллы плагиоклазов из базальтовых включений отличаются крайне незначительной зональностью в центральной части кристалла (см. рис. 4а) и наиболее основным составом среди всех изученных плагиоклазовых разностей $\left(\mathrm{An}_{84}-\mathrm{An}_{90}\right.$, см. вставку на рис. 4a). Ядра некоторых кристаллов содержат следы плавления (пунктирная линия, см. рис. 4а) и последующего залечивания роговой обманкой (белые фрагменты в центре ядра, см. рис. 4a), реже магнетитом, а также участками более кислого плагиоклаза $\left(\mathrm{An}_{77}\right)$ (см. рис. 4a). Внутренние части нерезорбированных кристаллов плагиоклазов из основных включений характеризуются низкими значениями Ва (0-50 ppm) и пониженным содержанием Sr (в основном 300-550 ppm), а также высокими концентрациями Fe (до 5000 ppm) и $\mathrm{Mg}$ (300-500 pрm). Краевые зоны таких кристаллов резко отличаются от внутренних и средних зон. В краевых зонах, которые варьируют от первых микрон до 100 микрон, наблюдается резкое падение анортитовой составляющей до $\mathrm{An}_{36}$, увеличение концентраций $\mathrm{Sr}$ и Ва до 900 ррm и 500 ppm, соответственно, и понижение концентраций Fe и Mg до 2800 ppm и 200 ppm, соответственно (см. рис. 4a). Составы крайних зон этих кристаллов близки по химическому составу близлежащим микролитам.

\section{2. Генерация кристаллов Pl-1 в дацитовых лавах}

Нерезорбированные кристаллы плагиоклаза из дацитовых лав характеризуются хорошо выраженной зональностью и зачастую довольно крупными размерами (до 2 см) (см. рис. 26, 5а). В отличие от вкрапленников P1-1 в базальтах, центральные и средние зоны P1-1 из дацитовых лав низкокальциевые $\left(\mathrm{An}_{40}-\mathrm{An}_{50}\right)$ и содержат высокие концентрации $\mathrm{Sr}(500-750$ ppm) и Ва (150$300 \mathrm{ppm})$ при пониженных значениях Fe (1500$2000 \mathrm{ppm})$ и $\mathrm{Mg}(100-150 \mathrm{ppm})$. В связи с тонкой зональностью этих кристаллов кривые распределения элементов в них сильно изрезаны, отражая вариации химических элементов в разных зонах одного кристалла (см. рис. 5а). Так же, как и в P11 из базальтовых включений, краевые части кристаллов P1-1 из дацитовых лав заметно отличаются от внутренних и средних зон, однако тенденция этих изменений по всем элементам здесь прямо противоположная: в краевых зонах наблюдается увеличение анортитовой компоненты (до $\mathrm{An}_{55}$ ), обогащение $\mathrm{Fe}$ (до 3500 ppm) и $\mathrm{Mg}$ (до $300 \mathrm{ppm})$ и обеднением Ва (<100 ppm) и $\mathrm{Sr}$ (до 500 ppm) (см. рис. 5а). Близлежащие микролиты также близки по составам каймам фенокристаллов. 

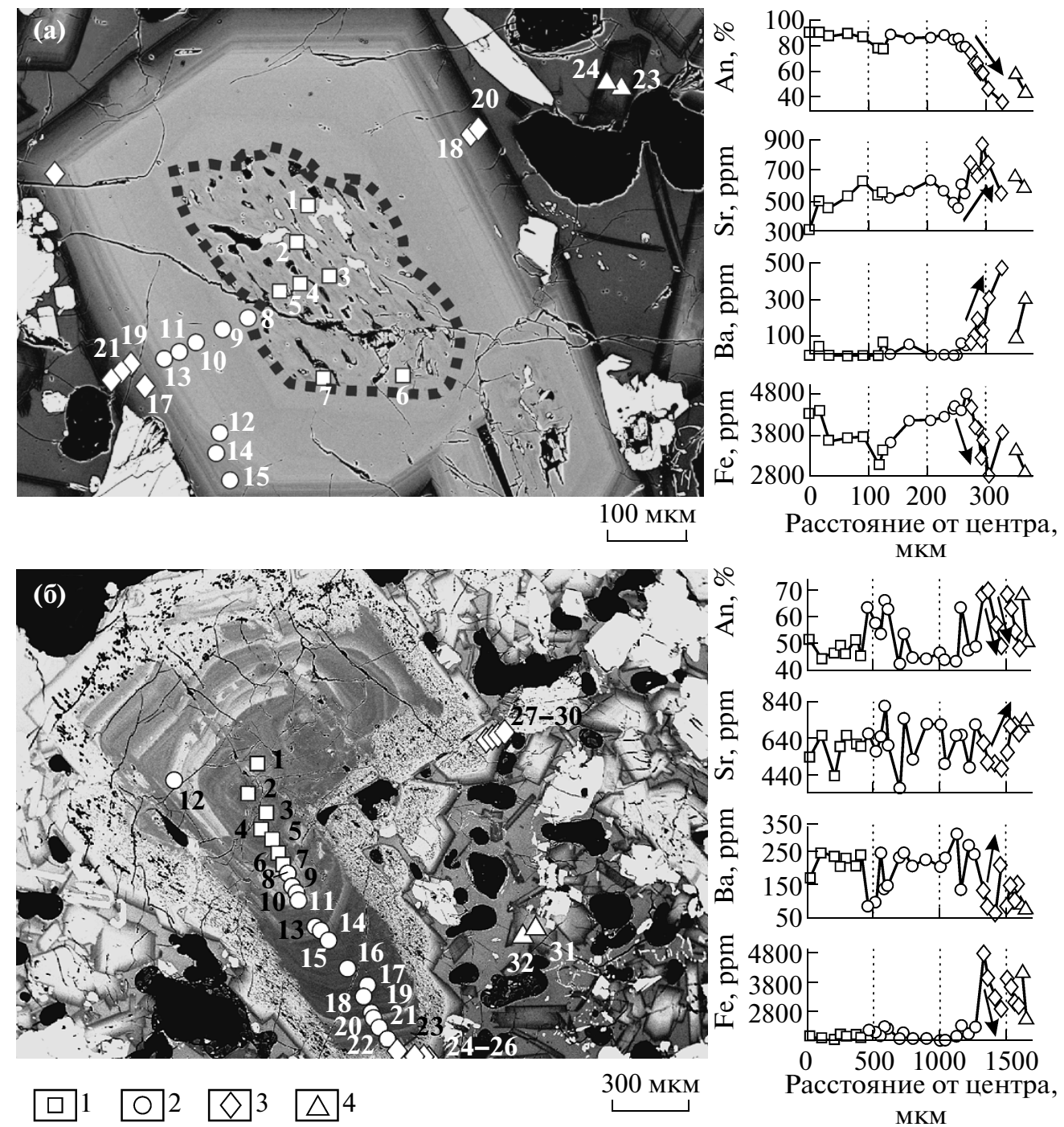

Рис. 4. Электронный микрозондовый профиль количественных точечных определений в типичных плагиоклазах из базальтовых включений в лавах вулкана Кизимен.

Цифрами указаны последовательно анализированные точки от центров к краям зерен (а) в нерезорбированном плагиоклазе (центр зерна показан пунктирной линией) и (б) в резорбированном плагиоклазе. На врезках - изменение содержаний $\mathrm{An}, \mathrm{Sr}, \mathrm{Ba}$, и $\mathrm{Fe}$ вдоль профиля. Для сравнения было проанализировано несколько зерен плагиоклазовых микролитов, находящихся вблизи изучаемых фенокристаллов. Стрелками указаны геохимические вариации на краях зерен, отражающие последний этап смешения магм перед извержением.

1 - центры вкрапленников, 2 - средние части вкрапленников, 3 - краевые зоны вкрапленников, 4 - микролиты. Точка 23 на рис. 4 соответствует зоне резорбции.

\section{3. Генерация кристаллов PI-2 во включениях и дацитовых лавах}

Как было отмечено выше, резорбированные кристаллы плагиоклазов (Pl-2) из дацитовых лав и базальтовых включений удивительно схожи между собой как по морфологии, так и по химическому составу. В структуре этих кристаллов ясно выделяются три основные зоны: (I) внутренняя - с хорошо выраженной зональностью, (II) зона резорбции, которая может варьировать от 50 до 200 микрон и (III) внешняя зона до 50 микрон (см. рис. 4б, 5б). Внутренние части плагиоклазов Pl-2 аналогичны по химическому составу внутренним частям Pl-1 из дацитовых лав, т.е. харак- теризуются низкими значениями $\mathrm{An}, \mathrm{Fe}$ и $\mathrm{Mg}$ при относительно высоких концентрациях Ва и Sr. B зоне резорбции плагиоклаз становится более основным - резко повышается содержание An компоненты (до $\mathrm{An}_{80}$ ), концентрации $\mathrm{Fe}$ и $\mathrm{Mg}$ (до $5000 \mathrm{ppm}$ и $550 \mathrm{ppm}$, соответственно) и снижаются содержания $\mathrm{Sr}$ и Ва. В краевой зоне III плагиоклаз опять становится более кислым, но содержание An в нем остается выше, чем в центральных частях зерен. Близлежащие к резорбированным зернам микролиты по химическому составу варьируют и соответствуют составу плагиоклаза Pl-2 в зонах II и III. 


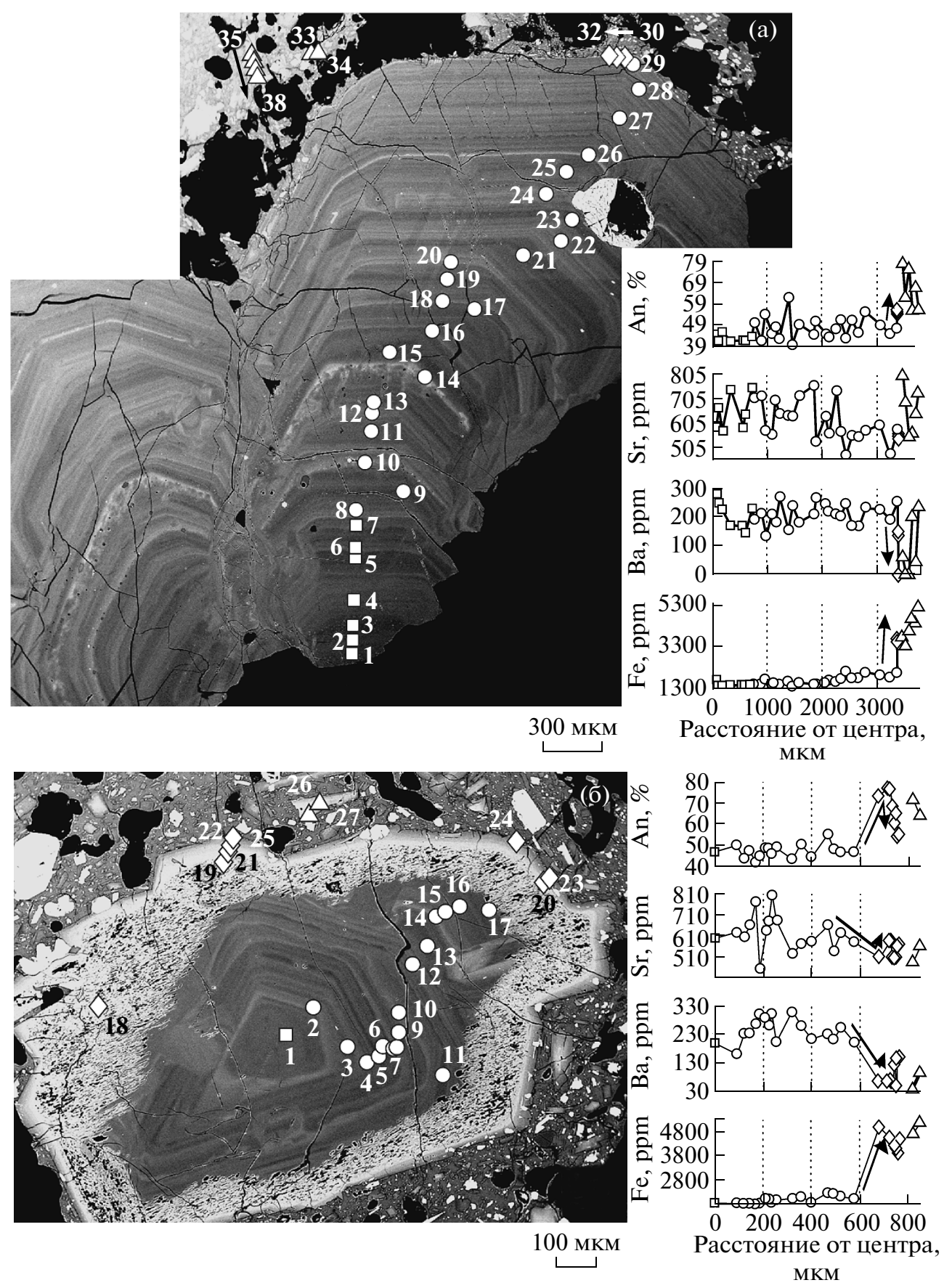

Рис. 5. Электронный микрозондовый профиль количественных точечных определений в типичных плагиоклазах из дацитовых лав вулкана Кизимен.

Цифрами указаны последовательно анализированные точки от центров к краям зерен (а) в нерезорбированном плагиоклазе размером более 2 см и (б) в резорбированном плагиоклазе (кайма резорбции более 0.1 см). Изменения составов кристаллов от центра к краю для $\mathrm{An}, \mathrm{Sr}, \mathrm{Ba}$, и $\mathrm{Fe}$ показаны на врезках. Для сравнения было проанализировано несколько зерен плагиоклазовых микролитов, находящихся вблизи изучаемых фенокристаллов. Точка 18 на рис. 56 соответствует зоне резорбции.

Условные обозначения см. рис. 4.

\section{5. ОБСУЖДЕНИЕ РЕЗУЛЬТАТОВ ИССЛЕДОВАНИЯ}

На диаграмме содержания $\mathrm{Mg}$ в зависимости от анортитовой составляющей в плагиоклазе (рис. 6) ясно обнаруживаются два поля точек, кото- рые тяготеют к зонам, отмеченным как ядра основных и кислых плагиоклазов. Ядра нерезорбированных зерен из базальтовых включений являются наиболее основными $\left(\mathrm{An}_{75}-\mathrm{An}_{94}\right)$ и наиболее обогащены $\mathrm{Mg}$ (300-550 ppm) в сравнении со всеми другими кристаллами (см. рис. 4, 5, 6). Эти высоко- 
анортитовые плагиоклазы с высоким содержанием магния, вероятно, росли в наиболее основном, высокомагнезиальном расплаве базальтового состава. Они всегда нерезорбированы и крайне редко встречаются во вмещающих породах. В отличие от них центральные и средние зоны нерезорбированных кристаллов из вмещающих пород аналогичны центральным и средним частям резорбированных кристаллов, как из дацитовых вмещающих пород, так и из базальтовых включений (см. рис. 46, 5, 6), и представлены низкоанортитовыми плагиоклазами $\left(\mathrm{An}_{40}-\mathrm{An}_{50}\right)$ с близкими содержаниями микрокомпонентов (в т.ч. низким содержанием Mg), что указывает на их формирование из единого низкомагнезиального дацитового расплава. Такие низкоанортитовые плагиоклазы, вероятно, росли из эволюционировавшего кислого расплава и встречаются как в несущих дацитовых лавах, так и в базальтовых включениях.

Составы средних зон и краев кристаллов свидетельствуют о различной истории расплавов, из которых они кристаллизовались. Нерезорбированные плагиоклазы из включений обнаруживают типичный тренд кристаллизационной дифференциации (тренд I, см. рис. 6б) с уменьшением An и содержания Mg от центра к краю кристалла. Средние и краевые зоны нерезорбированных плагиоклазов из вмещающих пород формируют два тренда. Один из них совпадает с трендом I, в то время как другой (тренд II, см. рис. 6б) характеризуется возрастанием An-составляющей от центра к краю при постоянном содержании $\mathrm{Mg}$. Эти два принципиально различных тренда предполагают различные контролирующие их процессы.

Тренд I может представлять собой не только классический тренд дифференциации основного расплава, но и тренд смешения кислого и основного расплавов с последующим ростом средних и краевых частей кристаллов из смешанного расплава. На процессы смешения указывает тот факт, что все кислые плагиоклазы (в том числе Pl-1 из несущего дацита и P1-2 как из дацита, так и из базальтовых включений) обнаруживают увеличение их основности от центра к краю (см. рис. 6б). Фракционная кристаллизация при отсутствии процессов смешения привела бы к изменению состава плагиоклаза только в сторону увеличения кислотности.

На процесс смешения кислого и основного расплавов указывает также обилие резорбированных плагиоклазовых фенокристаллов в обеих породах. При смешении низкотемпературных дацитовых лав, содержащих фенокристаллы плагиоклаза, и высокотемпературного базальтового расплава эти кристаллы попадают в перегретую среду. В результате в краевых частях кристаллов происходит растворение ранее образованного плагиоклаза и замещение его скелетными формами более основного плагиоклаза с формированием зоны резорбции. Состав плагиоклаза в этой зоне характеризуется максимальными для кристалла значениями содержаний An и $\mathrm{Mg}$ при минимальных концентрациях Ва и $\mathrm{Sr}$ (см. рис. 5б). Затем резорбированные плагиоклазы обрастают каймой, которая находится в равновесии с новым гибридным расплавом, по составу промежуточным между базальтовым и дацитовым. Из того же расплава растут и плагиоклазовые микролиты, что определяет их сходство с оторочками фенокристаллов.

При изучении средних зон всех (резорбированных и нерезорбированных) низко-An плагиоклазов отмечается хорошо выраженная зональность, причем светлые участки роста плагиоклазов отвечают составам с повышенным содержанием An, а темные - с пониженным (см. рис. 5а). Эта зональность хорошо прослеживается по увеличению $\mathrm{Mg}$ и $\mathrm{Fe}$ и уменьшению Ва и $\mathrm{Sr}$ в светлых зонах плагиоклазов и формирует соответствующее пилообразное распределение микроэлементов. Следовательно, в ходе эволюции системы процесс смешения кислого и основного расплавов происходил неоднократно. Вероятно, добавка именно последней порции базальтового расплава явилась спусковым крючком извержения, что запечатлено в резком изменении состава краевых зон кристаллов плагиоклаза.

Что касается кристаллов плагиоклаза, сформировавшихся из базальтового высокотемпературного расплава (Pl-1 в базальтовом включении, см. рис. 4a), то они не растворялись при смешении с низкотемпературной дацитовой магмой. Но на смешение с кислым расплавом указывает формирование кислых краевых зон вокруг высоко-Аn внутренних частей кристаллов, а именно, зон с уменьшенным содержанием $\mathrm{An}, \mathrm{Mg}$ и $\mathrm{Fe}$ и увеличенными концентрациями Ва и $\mathrm{Sr}$ (см. рис. 4a). Кристаллы Pl-1 из базальтовых включений мало реагируют на добавку кислого материала, чем объясняется их слабая зональность и довольно ровные профили распределения микроэлементов.

Кроме того, обилие полосчатых лав и включений андезибазальтов и базальтов в даците (см. рис. 2) также является уверенным признаком смешения расплавов, а наличие нескольких генераций включений (присутствие более основных включений внутри менее основных) говорит о многостадийности этого процесса (см. рис. 2б).

На рисунке 6 ядра низко-Аn плагиоклазов находятся на продолжении тренда I, отсюда можно предположить, что смешивающиеся расплавы могли быть в разной степени фракционированными лавами единого источника. На это указывают близость изотопных характеристик дацитов и базальтов (см. рис. 3в), а также сходство геохимических характеристик распределений микроэле- 
(a)

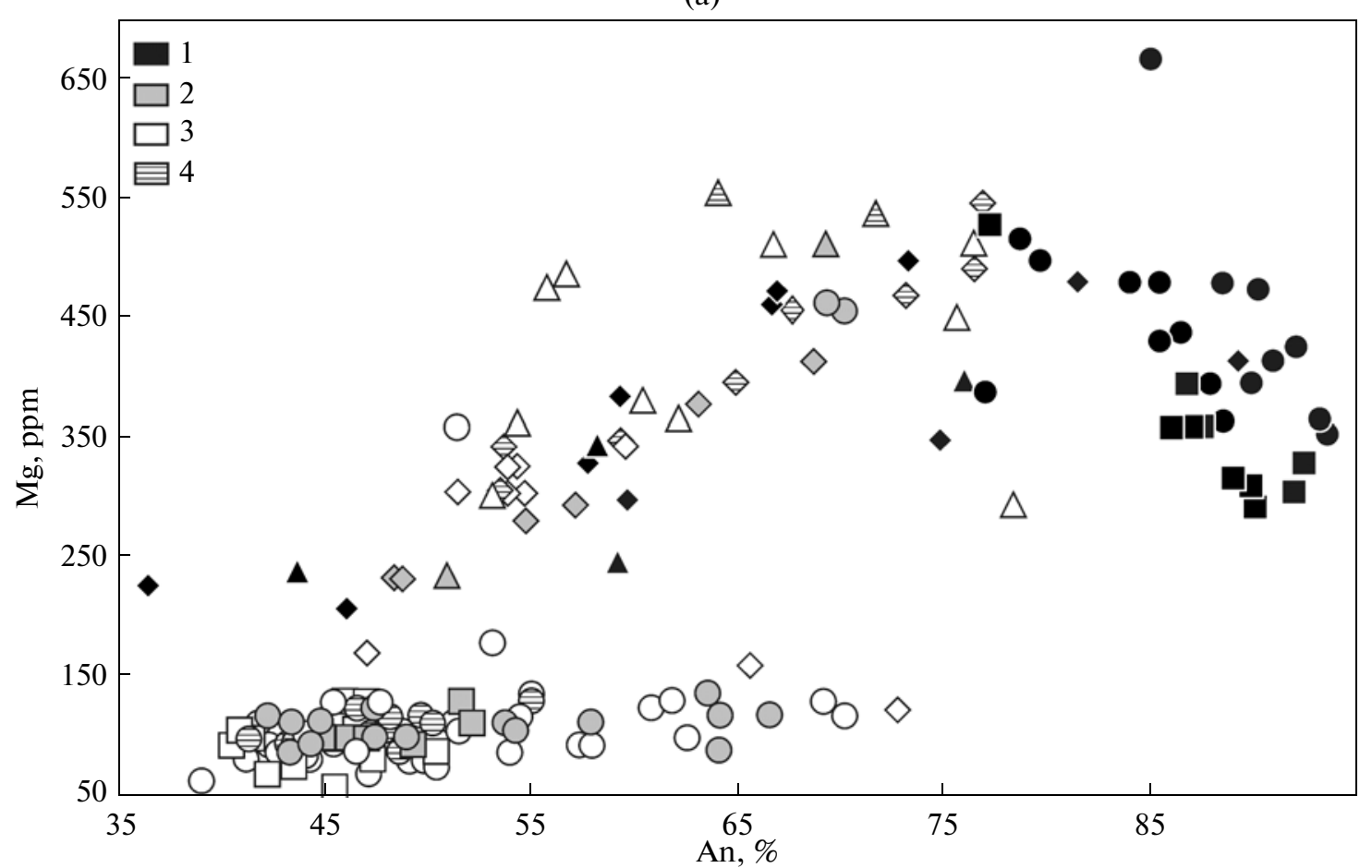

(б)

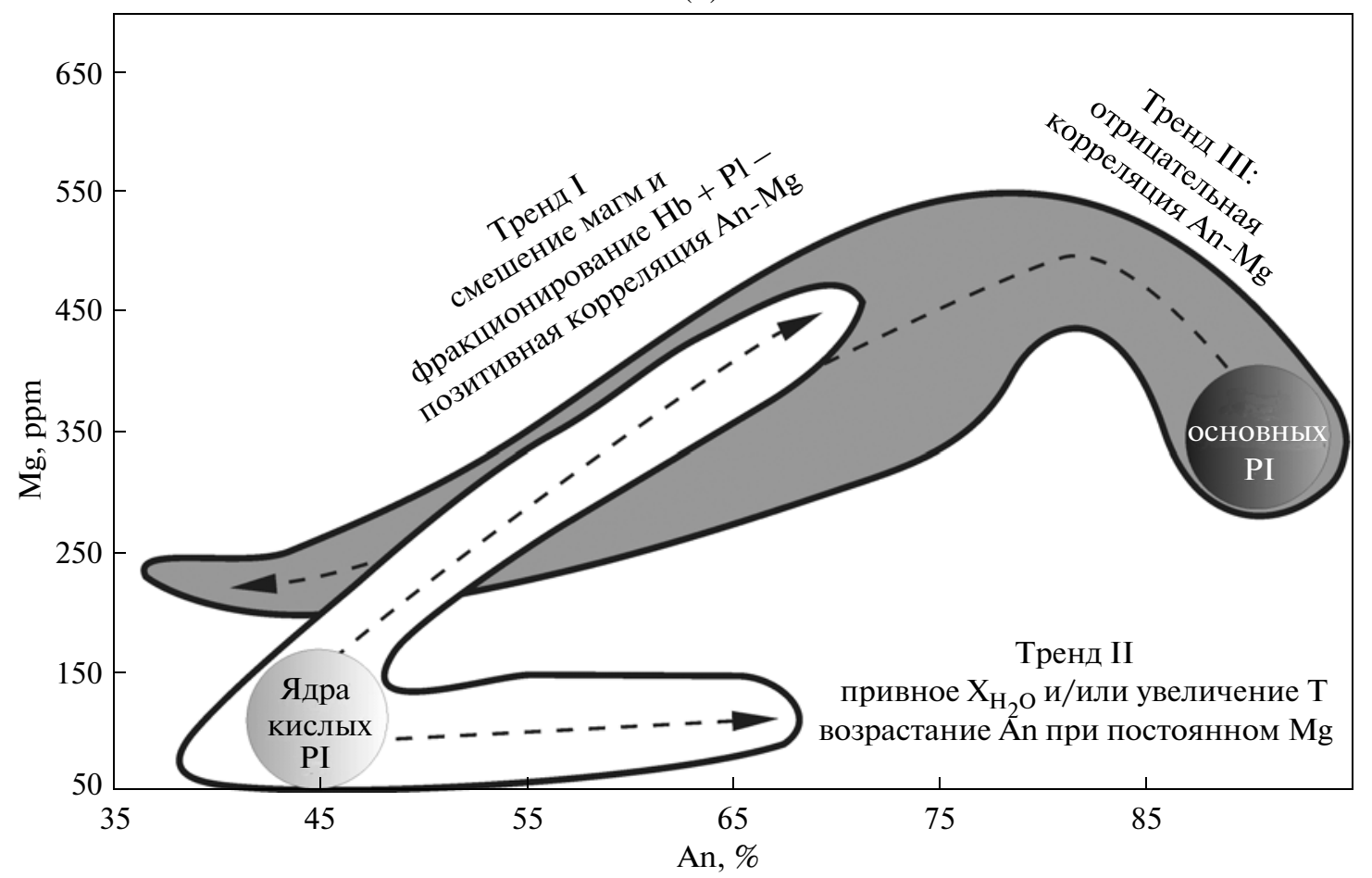

Рис. 6. Диаграмма зависимости $\mathrm{Mg}$ в плагиоклазе от его An номера (а). Форма символа обозначает расположение точки внутри кристалла: квадраты - центры кристаллов, кружки - средние зоны, ромбы - каймы кристаллов, треугольники - микролиты. 1 - Pl-1 из включений основного состава; 2 - Pl-2 из включений основного состава; 3 - Pl-1 из дацитовой вмещающей лавы; 4 - Pl-2 из дацитовой вмещающей лавы. Схема эволюции кристаллов, показанная стрелками от центров к краям зерен (б). Серые поля соответствуют высоко-Аn (основным) плагиоклазам из базальтовых и андезибазальтовых включений в лавах, белые поля показывают эволюцию низко-An (кислых) плагиоклазов как из лав, так и из включений в них. 
ментов. Это сходство проявляется в том, что все минимумы и максимумы на спайдер-диаграммах обоих типов пород совпадают.

Тренд II на рисунке $6 б$ связан с многократно повторяющимся изменением содержания An компоненты в плагиоклазе без соответствующего изменения в содержании Mg. Такое поведение состава плагиоклаза объясняется возрастанием температуры в магматическом очаге без изменения химического состава расплава. О повышении температуры свидетельствует кристаллизация более основного плагиоклаза, а о постоянстве химического состава системы - неизменное содержание $\mathrm{Mg}$ в плагиоклазе, которое в первую очередь контролируется содержанием $\mathrm{Mg}$ в расплаве. Возрастание температуры расплава может быть результатом нагрева дацитового расплава внедрившейся базальтовой высокотемпературной магмой. Такое возможно не в граничном слое смешения двух расплавов, а на некотором удалении от него, там, где не происходит физического и химического смешения двух расплавов, но температура дацитового расплава возрастает. Аналогичный эффект должен наблюдаться и при увеличении содержания воды в расплаве [Волынец и др., 1977].

Наконец, тренд III на рис. 6 характеризуется увеличением содержания $\mathrm{Mg}$ и в меньшей степени Fe [Чурикова и др., 2003; Churikova et al., 2007] при уменьшении An-компоненты в плагиоклазах. Такое поведение $\mathrm{Mg}$ нами наблюдалось только в центральных и средних частях высокоанортитовых нерезорбированных зерен плагиоклазов из базальтовых включений (см. рис. 6б). Логично предположить, что такие, наиболее основные плагиоклазы должны были формироваться из наиболее примитивных расплавов. Чтобы объяснить отрицательную корреляцию магния и анортита в кристалле, соответствующую тренду III, можно рассмотреть три следующих сценария.

\section{1. Продолжительное пополнение магматического очага горячими высоко-Mg расплавами с накоплением магния}

Существование структур резорбции в некоторых ядрах кристаллов Pl-1 из базальтовых включений (см. рис. 4а) может предполагать наличие событий смешения с более горячим расплавом на ранних стадиях кристаллизации плагиоклаза. Тем не менее, отрицательная корреляция между An, $\mathrm{Mg}$ и Fe в плагиоклазах P1-1 наблюдается не только в ядрах, но и в средних зонах вкрапленников, где резорбция отсутствует. Поэтому такой сценарий должен быть исключен из рассмотрения.

\section{2. Кристаллизация плагиоклаза как первой и единственной фазы}

Если коэффициент распределения магния $\mathrm{Kd}_{\mathrm{Mg}}$ в системе плагиоклаз-расплав не изменяется значительным образом [Bindeman et al., 1998], то логично предположить, что во время роста кристаллов с отрицательной $\mathrm{An}-\mathrm{Mg}$ корреляцией расплав обогащался магнием. Основными породообразующими минералами в породах вулкана являются оливин, пироксен, роговая обманка и плагиоклаз. Причем плагиоклаз присутствует во всех разностях пород. Количество оливина и пироксена уменьшается, а содержание роговой обманки возрастает от базальтов к дацитам, но зерна роговой обманки присутствуют и в основных породах. Эти же минералы присутствуют и в виде микролитов в основной массе, которая раскристаллизована в разной степени. Поскольку при кристаллизации Ol, Cрх и Нb содержание магния в расплаве будет стремительно падать, то обогащение расплава этим элементом возможно при фракционной кристаллизации только плагиоклаза, как первой и единственной фазы. Это объяснение может быть проверено модельными расчетами, если известны температура и давление кристаллизации.

Для выяснения условий кристаллизации внутри магматического очага и состава гибридной магмы перед извержением была проведена серия петрографических экспериментов в Геофизическом институте Университета Аляски (г. Фэрбенкс, США) [Browne et al., 2010; Browne et al., 2006]. Природные образцы дацитов вулкана Кизимен обнаруживают стабильную минералогическую ассоциацию: $\mathrm{Pl}+\mathrm{Opx}+\mathrm{Hbl}+\mathrm{Mt}+\mathrm{Ilm}$. Согласно магнетит-ильменитовому геотермометру [Stormer, 1983] была рассчитана равновесная температура кристаллизации, которая оказалась равной 815$825^{\circ} \mathrm{C}$. Именно при такой температуре вся минералогическая ассоциация дацита Кизимена (рис. 7а) была получена экспериментально. Эксперименты проводились при таких температурах и давлениях, в которых плагиоклаз был стабилен. На рис. $7 б$ показаны результаты анализов составов экспериментально полученных плагиоклазов в сравнении с природными плагиоклазовыми кромками из изученных дацитов. Ясно видно, что для равновесных температур кристаллизации $815-820^{\circ} \mathrm{C}$ природные составы лежат между экспериментальными составами, наблюдавшимися в экспериментах при 125 МПа и 150 МПа, предполагая равновесное давление около 125 МПа и температуру близкую к $820^{\circ} \mathrm{C}$. При этих же условиях составы стекол, полученных в экспериментах, соответствуют составам природных остаточных расплавов (см. рис. 7в, показаны данные для $\mathrm{SiO}_{2}$ и $\mathrm{FeO}$ ).

Таким образом, эксперименты показали, что последнее переуравновешивание дацитовой лавы 
(a)
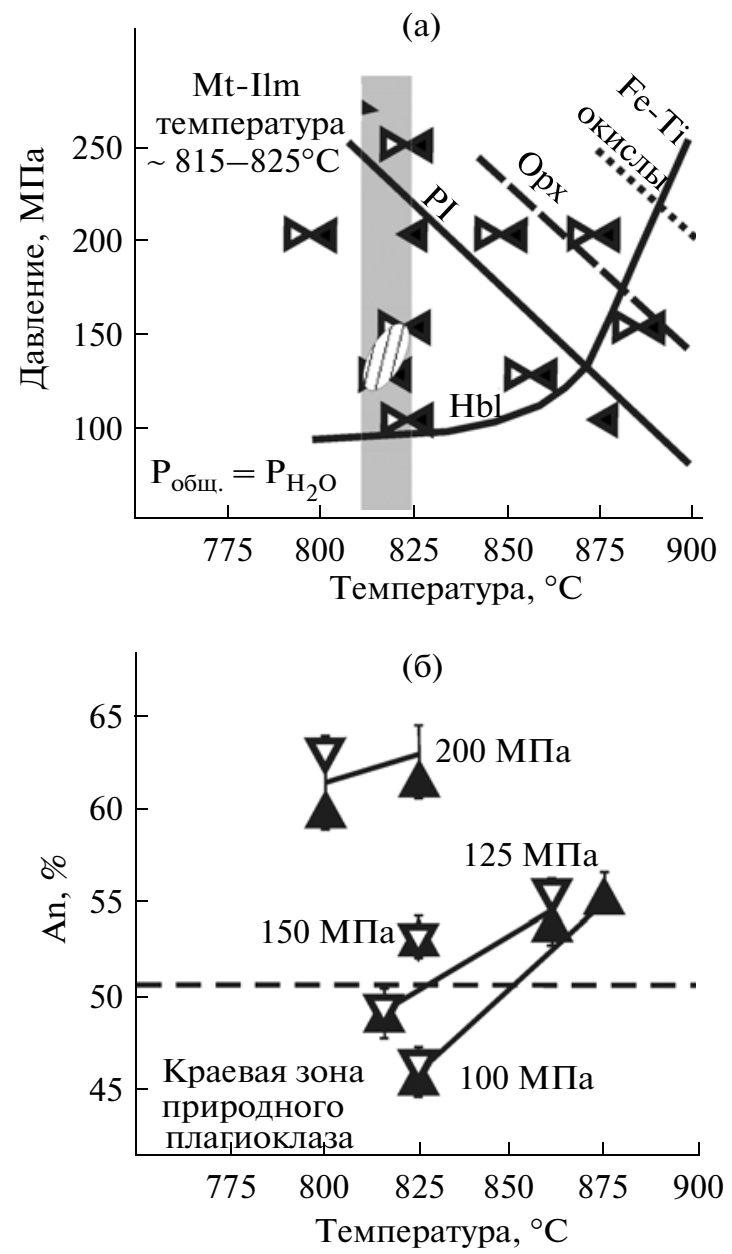
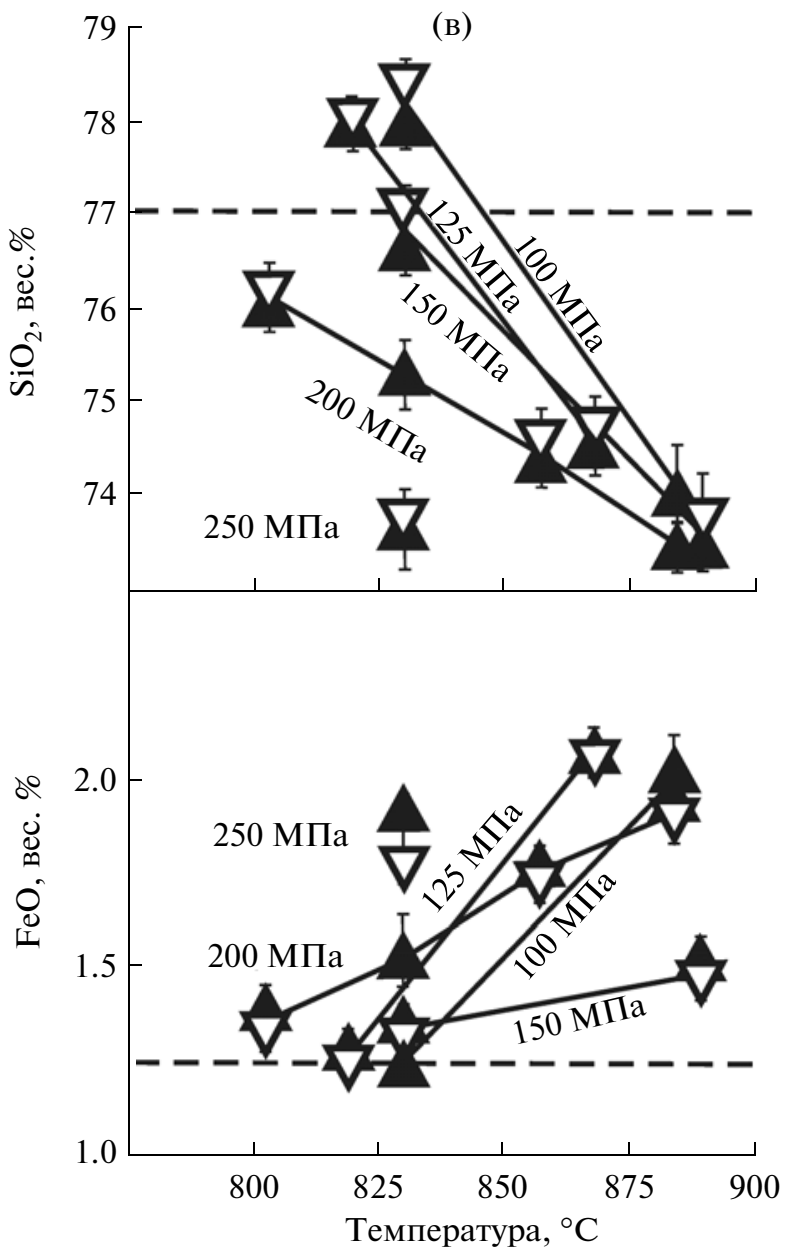

Рис. 7. Результаты петрографических экспериментов для пород вулкана Кизимен (по данным [Browne et al., 2006, 2010]). Фазовая диаграмма (7а), иллюстрирующая поля стабильности для минеральной ассоциации дацита вулкана Кизимен и Р-Т условия проведения эксперимента. Открытые и заполненные треугольники - эксперименты по кристаллизации и плавлению, соответственно. Сплошные и пунктирные линии - линии вхождения соответствующих породообразующих минералов. Заштрихованное поле - Р-Т условия стабильности дацита вулкана Кизимен непосредственно перед извержением, полученные по экспериментальным данным, геотермометрии, фазовой стабильности и составам сосуществующих стекла и минералов. Составы плагиоклазов (7б) в сравнении с краевой частью природного плагиоклаза из дацита Кизимена (пунктирная линия) при различных Р-Т условиях. Сравнение составов стекол (7в), полученных при различных температурах и давлениях в сравнении с природным стеклом дацита вулкана Кизимен (пунктирная линия). Сплошными линиями показаны эксперименты, выполненные при одном давлении.

вулкана Кизимен происходило при давлении $\sim 125$ МПа и температуре $\sim 820^{\circ} \mathrm{C}$ (см. рис. 7). При этих параметрах экспериментально были воспроизведены полная минеральная ассоциация исследуемого дацита (см. рис. 7a), состав природного плагиоклаза (см. рис. 7б) и состав остаточного расплава (см. рис. 7в).

Используя полученные экспериментальные данные, и предполагая, что магматический очаг по глубине в ходе эволюции расплава и последующего смешения не смещался, мы рассчитали модель фракционной кристаллизации для наиболее основного расплава базальтового включения вулкана Кизимен (см. табл. 1, высоко-Al базальт KIZ-01/1) на основе программного пакета COMAGMAT [Ariskin et al., 1993] при следующих условиях: $P=125$ МПа, $\mathrm{H}_{2} \mathrm{O}=1 \%$, буфер NNO [Churikova et al., 2007].

Как видно на рис. 8, модельные составы, полученные в расчетах, близи к наблюдаемым составам магм вулкана Кизимен. Хотя численная модель воспроизводит рост $\mathrm{Mg}$ и $\mathrm{Fe}$ в расплаве при одновременном уменьшении Ап в плагиоклазе на самых ранних стадиях кристаллизации (см. рис. 6а, 6б, 6е), тренды пород вулкана не обнаруживают соответствующих максимумов на графиках зависимости $\mathrm{MgO}$ и $\mathrm{FeO}$ от $\mathrm{SiO}_{2}$. Наблюдаемые составы оливина и пироксена хорошо воспроизводятся в рамках модели (модельные составы - $\mathrm{Fo}_{78.5-76}$ и $\mathrm{En}_{43-46} \mathrm{Fs}_{12-17} \mathrm{Wo}_{40-42}$, природные составы [Иванов, 2008; Мелекесцев и др., 1992] $\mathrm{Fo}_{79-75}$ и $\left.\mathrm{En}_{44} \mathrm{Fs}_{16} \mathrm{Wo}_{40}\right)$, 
Химический и изотопный состав пород вулкана Кизимен

\begin{tabular}{|c|c|c|c|c|c|c|c|c|c|c|}
\hline & TAM-01 & KIZ-01 & KIZ-01/1 & KIZ-02 & KIZ-04 & KIZ-05 & KIZ-07 & KIZ-07/1 & KIZ-08 & KIZ-09 \\
\hline$\overline{\mathrm{SiO}_{2}}$ & 51.40 & 63.60 & 49.70 & 62.40 & 60.60 & 56.20 & 60.10 & 52.90 & 57.70 & 63.30 \\
\hline $\mathrm{TiO}_{2}$ & 0.83 & 0.58 & 1.22 & 0.65 & 0.66 & 0.89 & 0.77 & 1.10 & 0.93 & 0.61 \\
\hline $\mathrm{Al}_{2} \mathrm{O}_{3}$ & 15.76 & 16.17 & 18.84 & 16.54 & 17.29 & 17.26 & 16.87 & 18.35 & 17.12 & 16.10 \\
\hline $\mathrm{Fe}_{2} \mathrm{O}_{3}$ & 9.37 & 2.41 & 5.32 & 2.69 & 2.75 & 3.43 & 3.83 & 4.22 & 3.63 & 2.41 \\
\hline $\mathrm{FeO}$ & 0.43 & 3.03 & 5.56 & 3.21 & 2.53 & 4.75 & 3.09 & 5.30 & 4.19 & 3.10 \\
\hline $\mathrm{MnO}$ & 0.19 & 0.13 & 0.19 & 0.14 & 0.13 & 0.17 & 0.15 & 0.19 & 0.17 & 0.13 \\
\hline $\mathrm{MgO}$ & 8.43 & 2.44 & 5.20 & 2.67 & 2.65 & 3.99 & 3.10 & 4.41 & 3.58 & 2.41 \\
\hline $\mathrm{CaO}$ & 9.23 & 5.34 & 9.25 & 5.89 & 5.63 & 7.17 & 6.34 & 8.48 & 7.07 & 5.42 \\
\hline $\mathrm{Na}_{2} \mathrm{O}$ & 2.72 & 3.69 & 2.74 & 3.73 & 3.61 & 3.27 & 3.58 & 3.26 & 3.44 & 3.74 \\
\hline $\mathrm{K}_{2} \mathrm{O}$ & 0.73 & 1.66 & 0.76 & 1.57 & 1.48 & 1.14 & 1.46 & 0.89 & 1.25 & 1.72 \\
\hline $\mathrm{P}_{2} \mathrm{O}_{5}$ & 0.23 & 0.16 & 0.17 & 0.15 & 0.19 & 0.16 & 0.16 & 0.19 & 0.18 & 0.15 \\
\hline LOI & 0.66 & 0.61 & 0.73 & 0.40 & 2.19 & 1.17 & 0.38 & 0.50 & 0.57 & 0.42 \\
\hline Total & 99.98 & 99.82 & 99.67 & 100.04 & 99.70 & 99.60 & 99.83 & 99.79 & 99.82 & 99.52 \\
\hline $\mathrm{Li}$ & 7.9 & 16.3 & 14.2 & & & 10.2 & & & & \\
\hline $\mathrm{Be}$ & 0.51 & 0.79 & 0.52 & & & 0.63 & & & & \\
\hline $\mathrm{Sc}$ & 31 & 15 & 26 & 17 & 15 & 21 & 18 & 26 & 24 & 15 \\
\hline V & 221 & 114 & 300 & 137 & 146 & 208 & 163 & 250 & 199 & 115 \\
\hline $\mathrm{Cr}$ & 481 & 17 & 15 & 16 & 26 & 10 & 12 & 11 & 19 & 13 \\
\hline Co & 36 & 14 & 30 & 18 & 14 & 29 & 17 & 26 & 21 & 13 \\
\hline $\mathrm{Ni}$ & 166 & 0 & 2 & 0 & 1 & 7 & 0 & 0 & 0 & 0 \\
\hline $\mathrm{Zn}$ & 79 & 55 & 79 & 61 & 57 & 68 & 63 & 74 & 65 & 55 \\
\hline $\mathrm{Ga}$ & 15 & 16 & 17 & 16 & 15 & 17 & 15 & 18 & 16 & 15 \\
\hline $\mathrm{Rb}$ & 15 & 38 & 14 & $34^{*}$ & $32 *$ & 26 & $31^{*}$ & $17 *$ & $25^{*}$ & $41 *$ \\
\hline $\mathrm{Sr}$ & 380 & 319 & 370 & 328 & 318 & 330 & 320 & 368 & 325 & 304 \\
\hline $\mathrm{Y}$ & 16 & 16 & 21 & $19 *$ & $15^{*}$ & 20 & $22 *$ & $24 *$ & $22 *$ & $18^{*}$ \\
\hline $\mathrm{Zr}$ & 86 & 121 & 86 & 124 & 115 & 102 & 117 & 96 & 117 & 126 \\
\hline $\mathrm{Nb}$ & 2.4 & 4.2 & 2.9 & $5.0^{*}$ & $6.0 *$ & 3.5 & $4.0 *$ & $3.0 *$ & $4.0^{*}$ & $4.0 *$ \\
\hline Cs & 0.50 & 1.5 & 0.52 & & & 0.47 & & & & \\
\hline $\mathrm{Ba}$ & 358 & 676 & 310 & 593 & 608 & 458 & 567 & 376 & 451 & 655 \\
\hline $\mathrm{La}$ & 7.62 & 10.16 & 5.85 & & & 7.73 & & & & \\
\hline $\mathrm{Ce}$ & 19.02 & 22.39 & 15.18 & & & 19.37 & & & & \\
\hline $\operatorname{Pr}$ & 2.69 & 3.32 & 2.34 & & & 2.76 & & & & \\
\hline $\mathrm{Nd}$ & 13.10 & 13.54 & 11.99 & & & 12.79 & & & & \\
\hline $\mathrm{Sm}$ & 3.72 & 2.89 & 3.36 & & & 3.23 & & & & \\
\hline $\mathrm{Eu}$ & 1.11 & 0.95 & 1.14 & & & 1.04 & & & & \\
\hline Gd & 3.29 & 2.58 & 3.28 & & & 2.97 & & & & \\
\hline $\mathrm{Tb}$ & 0.52 & 0.36 & 0.54 & & & 0.44 & & & & \\
\hline Dy & 3.38 & 2.28 & 3.33 & & & 2.94 & & & & \\
\hline Ho & 0.67 & 0.55 & 0.74 & & & 0.65 & & & & \\
\hline $\mathrm{Er}$ & 2.06 & 1.46 & 2.18 & & & 1.85 & & & & \\
\hline $\mathrm{Tm}$ & 0.32 & 0.20 & 0.30 & & & 0.26 & & & & \\
\hline $\mathrm{Yb}$ & 2.05 & 1.39 & 2.00 & & & 1.72 & & & & \\
\hline $\mathrm{Lu}$ & 0.31 & 0.24 & 0.29 & & & 0.28 & & & & \\
\hline $\mathrm{Hf}$ & 2.27 & 1.91 & 1.99 & & & 1.88 & & & & \\
\hline $\mathrm{Ta}$ & 0.19 & 0.21 & 0.17 & & & 0.17 & & & & \\
\hline $\mathrm{Tl}$ & 0.03 & 0.27 & 0.10 & & & 0.10 & & & & \\
\hline $\mathrm{Pb}$ & 2.15 & 5.30 & 1.95 & & & 3.01 & & & & \\
\hline Th & 0.91 & 3.19 & 1.02 & & & 1.42 & & & & \\
\hline $\mathrm{U}$ & 0.45 & 1.45 & 0.49 & & & 0.79 & & & & \\
\hline${ }^{87} \mathrm{Sr} /{ }^{86} \mathrm{Sr}$ & & & 0.703352 & & & & & & & \\
\hline${ }^{143} \mathrm{Nd} /{ }^{144} \mathrm{Nd}$ & & & 0.513045 & & & & & & & \\
\hline${ }^{206} \mathrm{~Pb} /{ }^{204} \mathrm{~Pb}$ & & & & & & & & & & \\
\hline${ }^{208} \mathrm{~Pb} /{ }^{204} \mathrm{~Pb}$ & & & & & & & & & & \\
\hline${ }^{207} \mathrm{~Pb} /{ }^{204} \mathrm{~Pb}$ & & & & & & & & & & \\
\hline
\end{tabular}


Продолжение

\begin{tabular}{|c|c|c|c|c|c|c|c|c|c|}
\hline & KIZ-11 & KIZ-17/2 & KIZ-18 & KIZ-19 & KIZ-21 & KIZ-22 & KIZ-23 & KIZ-24 & KIZ-24/1 \\
\hline$\overline{\mathrm{SiO}_{2}}$ & 55.70 & 57.30 & 61.60 & 50.30 & 55.40 & 61.30 & 63.60 & 54.70 & 51.60 \\
\hline $\mathrm{TiO}_{2}$ & 0.97 & 0.84 & 0.67 & 1.20 & 1.07 & 0.64 & 0.58 & 1.03 & 1.28 \\
\hline $\mathrm{Al}_{2} \mathrm{O}_{3}$ & 17.61 & 17.19 & 16.50 & 16.50 & 17.22 & 16.54 & 16.14 & 17.44 & 17.91 \\
\hline $\mathrm{Fe}_{2} \mathrm{O}_{3}$ & 2.90 & 2.76 & 2.46 & 2.97 & 3.14 & 3.08 & 2.60 & 3.07 & 4.29 \\
\hline $\mathrm{FeO}$ & 5.52 & 4.84 & 3.52 & 8.01 & 4.96 & 2.91 & 2.74 & 5.49 & 5.78 \\
\hline $\mathrm{MnO}$ & 0.17 & 0.17 & 0.14 & 0.21 & 0.18 & 0.13 & 0.13 & 0.17 & 0.19 \\
\hline $\mathrm{MgO}$ & 4.16 & 4.14 & 2.72 & 5.22 & 3.05 & 2.86 & 2.37 & 4.16 & 4.42 \\
\hline $\mathrm{CaO}$ & 7.70 & 7.24 & 5.84 & 9.59 & 7.36 & 5.71 & 5.32 & 8.18 & 9.13 \\
\hline $\mathrm{Na}_{2} \mathrm{O}$ & 3.30 & 3.33 & 3.76 & 2.70 & 3.66 & 3.51 & 3.69 & 3.18 & 3.03 \\
\hline $\mathrm{K}_{2} \mathrm{O}$ & 1.14 & 1.28 & 1.52 & 0.71 & 1.37 & 1.40 & 1.66 & 1.10 & 0.87 \\
\hline $\mathrm{P}_{2} \mathrm{O}_{5}$ & 0.17 & 0.18 & 0.15 & 0.21 & 0.26 & 0.16 & 0.15 & 0.17 & 0.19 \\
\hline LOI & 0.33 & 0.34 & 0.71 & 1.87 & 1.78 & 1.15 & 0.61 & 0.47 & 0.85 \\
\hline Total & 99.67 & 99.60 & 99.59 & 99.48 & 99.46 & 99.39 & 99.60 & 99.16 & 99.53 \\
\hline $\mathrm{Li}$ & & & & 3.8 & & & & 8.5 & 11.7 \\
\hline $\mathrm{Be}$ & & & & 0.44 & & & & 0.56 & 0.56 \\
\hline $\mathrm{Sc}$ & 21 & 22 & 18 & 35 & 26 & 16 & 13 & 22 & 33 \\
\hline V & 220 & 190 & 133 & 316 & 187 & 130 & 108 & 246 & 324 \\
\hline $\mathrm{Cr}$ & 16 & 47 & 20 & 42 & 11 & 34 & 19 & 24 & 21 \\
\hline $\mathrm{Co}$ & 27 & 20 & 21 & 37 & 20 & 14 & 13 & 27 & 27 \\
\hline $\mathrm{Ni}$ & 6 & 20 & 1 & 25 & 0 & 8 & 2 & 2 & 0 \\
\hline $\mathrm{Zn}$ & 71 & 76 & 58 & 94 & 83 & 60 & 57 & 72 & 80 \\
\hline $\mathrm{Ga}$ & 16 & 17 & 16 & 18 & 19 & 15 & 15 & 19 & 17 \\
\hline $\mathrm{Rb}$ & $24 *$ & $28 *$ & $33^{*}$ & 9 & $15^{*}$ & $30 *$ & $36^{*}$ & 21 & 16 \\
\hline $\mathrm{Sr}$ & 332 & 359 & 324 & 276 & 299 & 341 & 320 & 328 & 335 \\
\hline$Y$ & $23^{*}$ & $24 *$ & $20 *$ & 32 & $34 *$ & $15^{*}$ & $19 *$ & 20 & 23 \\
\hline $\mathrm{Zr}$ & 98 & 124 & 124 & 104 & 140 & 109 & 124 & 99 & 90 \\
\hline $\mathrm{Nb}$ & $4.0 *$ & $4.0 *$ & $3.0 *$ & 4.1 & $6.0 *$ & $3.0 *$ & $4.0 *$ & 3.1 & 3.2 \\
\hline Cs & & & & 0.31 & & & & 0.79 & 0.59 \\
\hline $\mathrm{Ba}$ & 459 & 466 & 606 & 164 & 200 & 591 & 669 & 419 & 323 \\
\hline $\mathrm{La}$ & & & & 6.49 & & & & 6.52 & 7.02 \\
\hline $\mathrm{Ce}$ & & & & 19.11 & & & & 16.57 & 18.10 \\
\hline $\operatorname{Pr}$ & & & & 2.73 & & & & 2.83 & 2.59 \\
\hline $\mathrm{Nd}$ & & & & 13.11 & & & & 12.73 & 13.08 \\
\hline $\mathrm{Sm}$ & & & & 3.86 & & & & 3.25 & 3.91 \\
\hline $\mathrm{Eu}$ & & & & 1.14 & & & & 1.08 & 1.27 \\
\hline Gd & & & & 4.04 & & & & 3.12 & 3.53 \\
\hline $\mathrm{Tb}$ & & & & 0.70 & & & & 0.47 & 0.63 \\
\hline Dy & & & & 4.37 & & & & 3.08 & 3.88 \\
\hline Ho & & & & 0.94 & & & & 0.76 & 0.75 \\
\hline $\mathrm{Er}$ & & & & 2.89 & & & & 1.97 & 2.23 \\
\hline $\mathrm{Tm}$ & & & & 0.42 & & & & 0.27 & 0.34 \\
\hline $\mathrm{Yb}$ & & & & 2.77 & & & & 1.72 & 2.38 \\
\hline $\mathrm{Lu}$ & & & & 0.42 & & & & 0.30 & 0.32 \\
\hline $\mathrm{Hf}$ & & & & 2.80 & & & & 2.10 & 2.17 \\
\hline $\mathrm{Ta}$ & & & & 0.21 & & & & 0.14 & 0.19 \\
\hline $\mathrm{Tl}$ & & & & 0.05 & & & & 0.09 & 0.10 \\
\hline $\mathrm{Pb}$ & & & & 2.03 & & & & 2.73 & 2.63 \\
\hline $\mathrm{Th}$ & & & & 0.59 & & & & 1.57 & 0.91 \\
\hline & & & & 0.38 & & & & 0.77 & 0.61 \\
\hline${ }^{87} \mathrm{Sr} /{ }^{86} \mathrm{Sr}$ & & & & & & & & 0.703347 & 0.70337 \\
\hline${ }^{143} \mathrm{Nd} /{ }^{144} \mathrm{Nd}$ & & & & & & & & 0.513048 & 0.513047 \\
\hline${ }^{206} \mathrm{~Pb} /{ }^{204} \mathrm{~Pb}$ & & & & & & & & & 18.32 \\
\hline${ }^{208} \mathrm{~Pb} /{ }^{204} \mathrm{~Pb}$ & & & & & & & & & 38.033 \\
\hline${ }^{207} \mathrm{~Pb} /{ }^{204} \mathrm{~Pb}$ & & & & & & & & & 15.5 \\
\hline
\end{tabular}

Примечание. Макроэлементы, Sc, V, Cr, Co, Ni, Zn, Ga, Sr, Zr, Ва и элементы, помеченные звездочкой, были определены методом РФА, остальные концентрации были получены методом ICP-MS. Образцы KIZ-17/2, KIZ-19, KIZ-21, KIZ-22 относятся к древнему основанию вулкана и не рассматриваются в рамках настоящего исследования. Остальные образцы возраста $\mathrm{Q}_{4}$. 


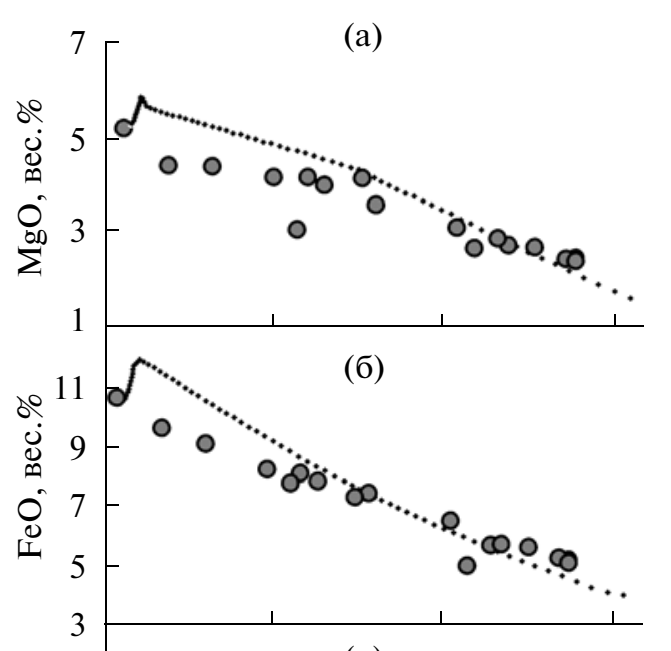

(B)
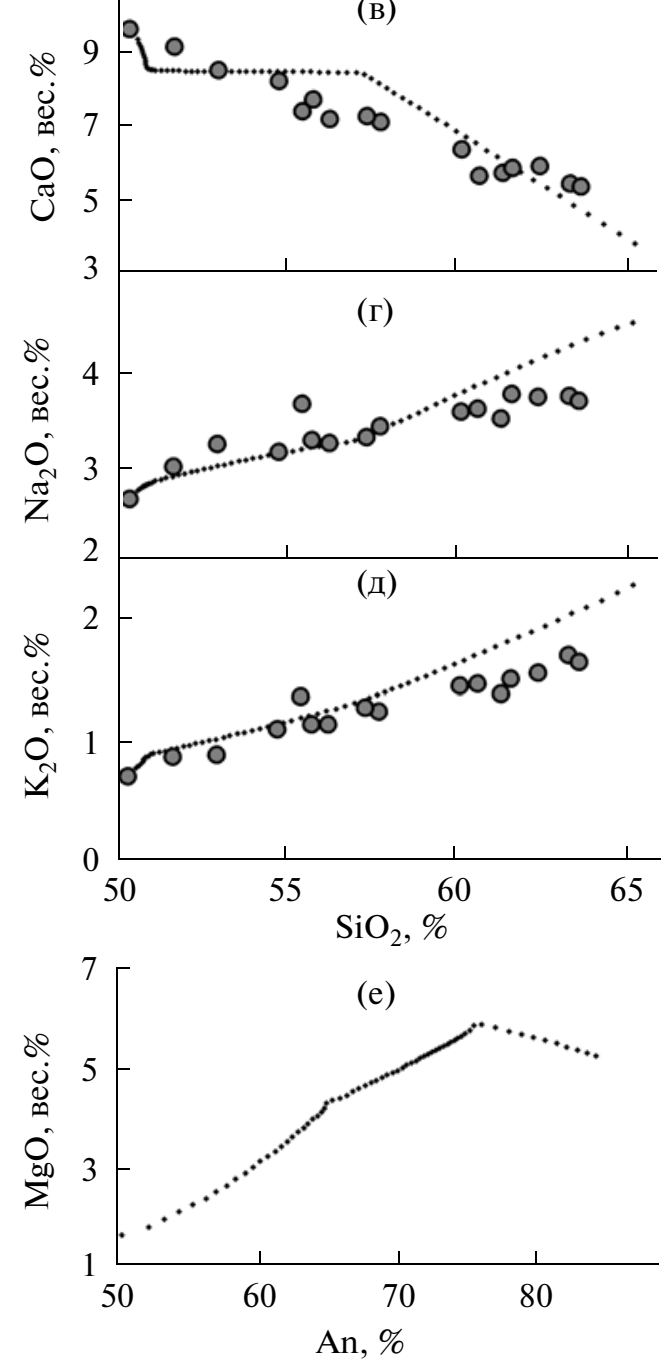

Рис. 8. Численная модель (пунктирная линия) фракционной кристаллизации базальтовой магмы вулкана Кизимен (образец KIZ-96-01/1) в сравнении с реальными составами пород (серые кружки). Расчеты осуществлялись по программе COMAGMAT [Ariskin et al., 1993] при условиях: $P=125$ МПа, буфер NNO и $\mathrm{H}_{2} \mathrm{O}=1 \%$. Благодаря фракционированию $\mathrm{Pl}$ на первых стадиях кристаллизации остаточный расплав обогащается по $\mathrm{MgO}$. но наиболее кальциевый плагиоклаз в расчетах имеет состав $\mathrm{An}_{84-85}$, в то время как ядра и средние зоны Pl-1 из базальтовых включений обнаруживают значения до $\mathrm{An}_{93.6}$ (см. табл. 2 в работе [Churikova et al., 2007]). Поэтому мы считаем, что состав, с которого начинался расчет, не являлся первичным. Низкие значения $\mathrm{MgO}$ (4-5\%), $\mathrm{Ni}$ (менее $2 \mathrm{ppm}$ ), $\mathrm{Cr}$ (11-20 ppm) и относительно высокие значения $\mathrm{K}_{2} \mathrm{O}(0.9 \%)$ свидетельствуют о том, что сами базальтовые включения являются уже фракционированными расплавами, а наличие зон резорбции в ядрах Pl-1 и присутствие многочисленных включений внутри более крупных включений (см. рис. 2б) говорит о многократных процессах смешения в основных магмах. Условия, при которых Pl может кристаллизоваться как первая фаза, крайне ограничены - по нашим расчетам такое возможно только при давлениях 1-3 Kbar (до 10 км). При кристаллизации же из родительского, более магнезиального расплава, такой сценарий вообще невозможен.

Таким образом, хотя принципиальная возможность кристаллизации плагиоклаза как первой фазы из высоко-Al гибридных расплавов в приповерхностных условиях существует, этот процесс не может контролировать распределение $\mathrm{MgO}$ и $\mathrm{FeO}$ в наиболее основных и наиболее кальциевых плагиоклазах.

\section{3. Нелинейное поведение \\ коэффициента распределения $\mathrm{Kd} \mathrm{Mg}_{\mathrm{Mg}}$ в системе расплав - плагиоклаз}

Автор работы [Sato, 1989] отмечал, что из-за кинетической неравновесности коэффициенты распределения, определяемые в экспериментах, могут значительно отличаться от равновесных значений, наблюдаемых в реальных природных системах. Экспериментально определенные коэффициенты распределения $\mathrm{Kd}_{\mathrm{Mg}}$ варьируют в узких пределах и почти независимы от состава расплава [Bindeman et al., 1998], исходя из предположения положительной корреляции $\mathrm{An}$ и $\mathrm{Mg}$ в плагиоклазах. Именно такая корреляция наблюдается для относительно кислых(см. рис. 6б, тренд I), но не для высокоанортитовых плагиоклазов вулкана Кизимен. Необходимо отметить, что большинство экспериментальных работ по определению $\mathrm{Kd}_{\mathrm{Mg}}$ и $\mathrm{Kd}_{\mathrm{Fe}}$ проводилось для плагиоклазов до $\mathrm{An}_{85}$ [S evers et al., 2009] в то время как тренд III располагается в области $\mathrm{An}_{75-93}$, где ясно наблюдается отрицательная корреляция An и $\mathrm{Mg}$ (см. рис. 6б, тренд III). Это может свидетельствовать о нелинейном поведении коэффициентов распределения $\mathrm{Kd}_{\mathrm{Mg}}$ и $\mathrm{Kd}_{\mathrm{Fe}}$ в высоко-Аn плагиоклазах. Ниже будет показано, что отрицательная корреляция $\mathrm{An}$ и $\mathrm{Mg}(\mathrm{Fe})$ в высоко-An плагиоклазах наблюдается не только на вулкане Кизимен, 

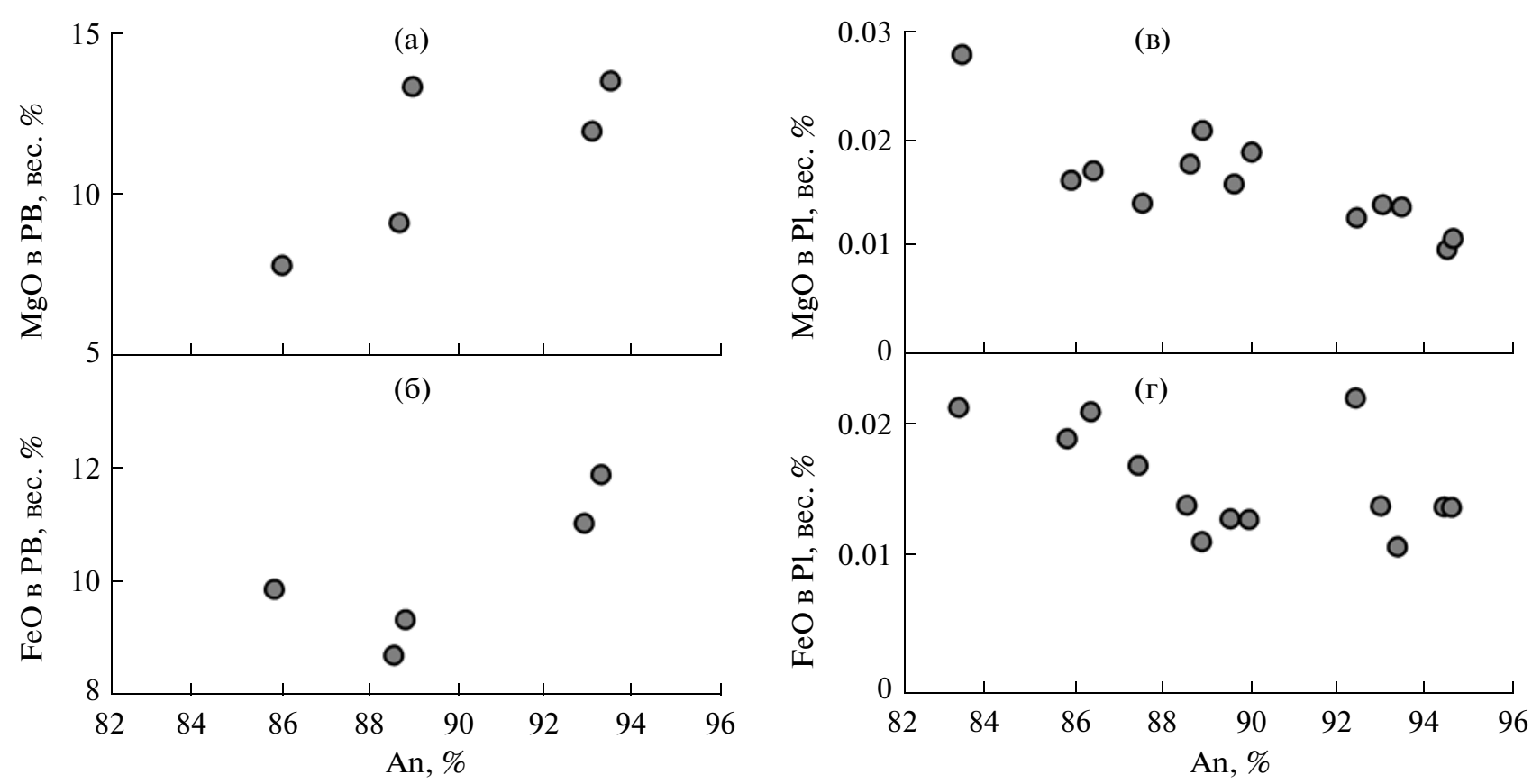

Рис. 9. Содержания $\mathrm{MgO}$ и $\mathrm{FeO}$ в расплавных включениях в плагиоклазах (а, б) и в плагиоклазах (в, г) в зависимости от An компоненты плагиоклаза из базальтов MORB рифта Коста-Рика (скв. 896А; данные из табл. 3,7 по [McNeill \& Danyushevsky, 1996]). РВ - расплавное включение.

но и в других, еще более примитивных магматических системах.

Авторы работы [McNeill, Danyushevsky, 1996] изучали расплавные включения в минералах базальтов срединно-океанических хребтов (MORB) рифта Коста-Рика (скв. 896А), где оливин, клинопироксен и шпинель являлись первыми кристаллизующимися фазами. Согласно их данным, содержания An в плагиоклазах и концентрации $\mathrm{MgO}$ и $\mathrm{FeO}$ в равновесных расплавах имеют положительную корреляцию (см. табл. 3, 7 в работе [McNeill, Danyushevsky, 1996]). Однако, если по данным этой работы построить графики зависимостей концентраций $\mathrm{MgO}$ и $\mathrm{FeO}$ от содержания An в плагиоклазе (рис. 9), то становятся ясно видимыми тренды отрицательной корреляции во всех кальциевых $\left(\mathrm{An}_{83}-\mathrm{An}_{95}\right)$ плагиоклазах. Это означает, что в то время как содержание $\mathrm{Mg}$ в расплаве уменьшалось, в плагиоклазе, кристаллизующемся из этого расплава, оно возрастало.

Аналогичное поведение концентрации $\mathrm{FeO}$, демонстрирующее отрицательную корреляцию с анортитом в плагиоклазах, наблюдалось для различных четвертичных вулканических пород Камчатки и Курильских островов (см. рис. 3 из работы [Волынец и др., 1977]).

Таким образом, можно предположить, что негативная корреляция между концентрациями $\mathrm{Mg}$ или Fе и содержанием An в высоко-Аn плагиоклазах является результатом нелинейного поведения коэффициентов распределения магния $\mathrm{Kd}_{\mathrm{Mg}}$ и железа $\mathrm{Kd}_{\mathrm{Fe}}$ в системе плагиоклаз-расплав. Ранее это явление не отмечалось, и это требует проведения экспериментальных работ по изучению коэффициентов распределения в высоко-An плагиоклазах.

На рис. 10 приведена схематическая модель магматической системы под вулканом Кизимен, которая иллюстрирует рассмотренные здесь процессы. Основная магма, содержащая высоко-An кристаллы Pl-1, внедряется в дацитовый магматический очаг с низко-An кристаллами $\mathrm{Pl}-1$, и происходит взаимодействие двух магм. Этот процесс формирует гибридные магмы, в которых две контрастные зоны - базальтовая и дацитовая обнаруживают признаки как химического, так и теплового взаимодействия (см. рис. 2в). Кристалл Pl-1 из дацита, проникающий в основную магму, подвергается тепловому воздействию, что приводит к его растворению и переходу из генерации Pl-1 в Pl-2. Новый более основной гибридный расплав образуется вокруг этого плагиоклаза, благодаря чему вокруг кристалла формируется кальциевая кайма (тренд I, см. рис. 6). Некоторые такие плагиоклазы возвращаются в дацитовую магму, другие же остаются в базальтовом включении.

Кристалл Pl-1 из высокотемпературного базальта при контакте с низкотемпературной дацитовой магмой не изменяется и не резорбирует. Но он обрастает более кислой каймой из гибридного, более кислого расплава. Такие плагиоклазы 


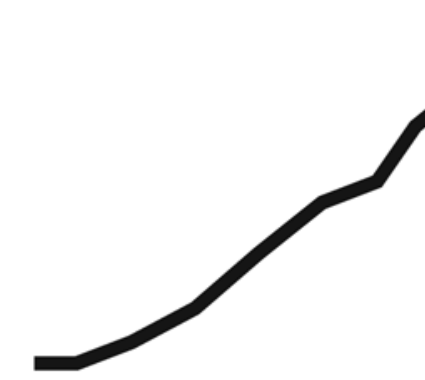

Аналогичные примеры:

Унзен, Япония

Пинатубо, Филиппины

Гора Дуттон, Аляска

Лассен-Пик, Калифорния

Суфрийер, Монтсеррат

Дацит Кизимена:

$\mathrm{Pl}+\mathrm{Hbl}+\mathrm{Opx}+\mathrm{Mt}-\mathrm{Ilm}$

$\sim 125$ МПа и $810-825^{\circ} \mathrm{C}$

$$
f_{\mathrm{O}_{2}} \sim \mathrm{NNO}+2
$$

$4.5-5$ вес. $\% \mathrm{H}_{2} \mathrm{O}$

содержит большое количество

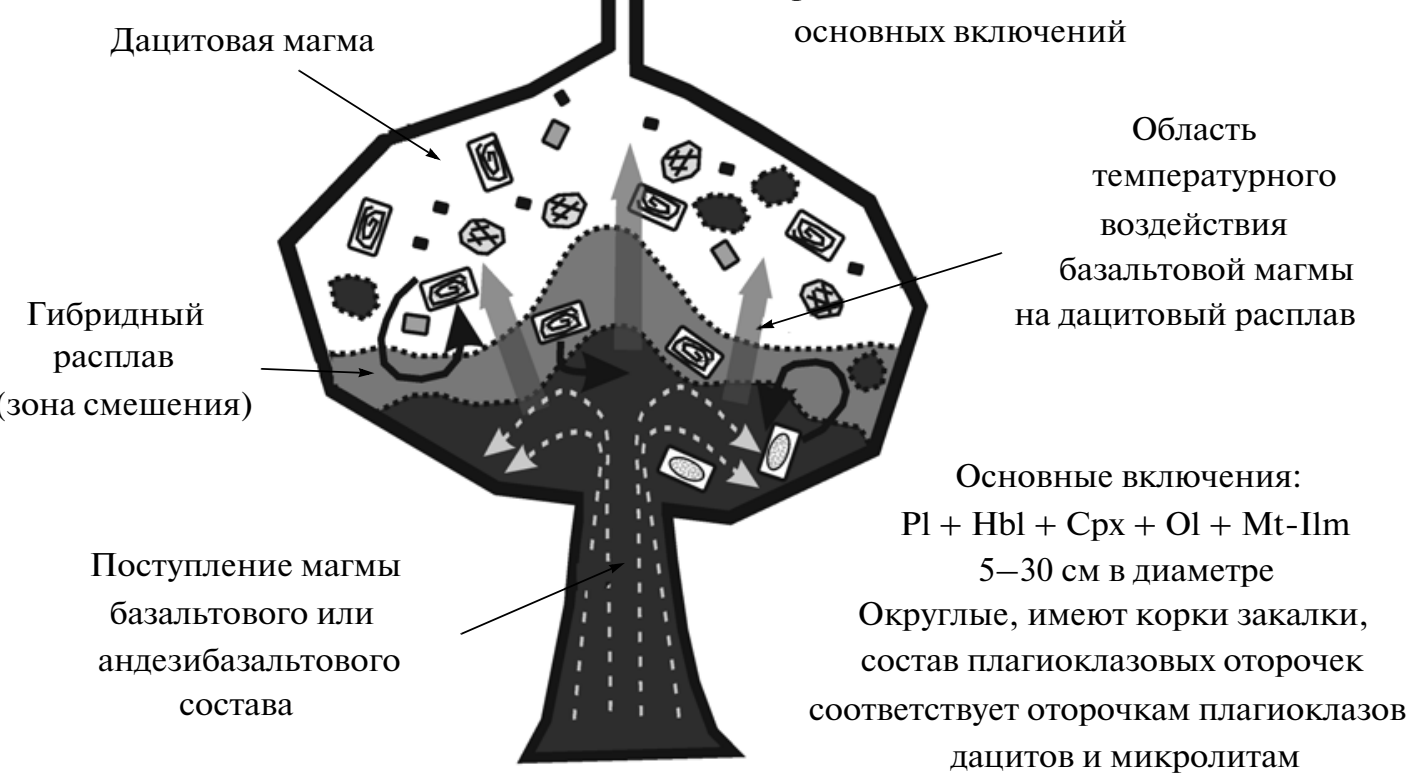

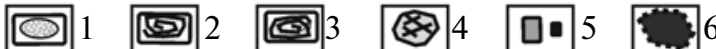

Рис. 10. Схема процессов, происходящих в магматическом очаге под вулканом Кизимен.

1 - нерезорбированные зерна плагиоклаза (Pl-1) в основной магме; 2 - нерезорбированные зерна плагиоклаза (Pl-1) в дацитовой магме; 3 - резорбированные зерна плагиоклаза (Pl-2); 4 - кристаллы роговой обманки; 5 - субфенокристаллы и микролиты; 6 - включения базальтового расплава в даците. Черными изогнутыми стрелками указаны основные направления передвижений плагиоклазовых фенокристаллов внутри магматического очага.

встречаются и в базальтовых включениях, и в дацитовой лаве.

Однако процессы смешения не были настолько эффективны, чтобы вовлечь в процесс смешения весь объем магмы и привести весь материал магматического очага к полной гомогенизации. Некоторые порции дацитовой магмы не имели прямого контакта с базальтовыми расплавами и не вовлекались в процессы химического смешения, но подвергались тепловому воздействию от поступившего высокотемпературного расплава. При возрастании температуры краевые зоны кислых фенокристаллов P1-1 становились более высоко-An, формируя тренд II (см. рис. 6). 
Мы считаем, что подъем и внедрение базальтовой магмы в дацитовый очаг на вулкане Кизимен происходили довольно часто, что приводило к образованию большого количества базальтовых включений. Комплексное взаимодействие между магмами на Кизимене обнаруживает много общего с аналогичными процессами на вулкане Унзен (Япония) [Eichelberger et al., 2000] и на многих других вулканах (см. рис. 10).

\section{ЗАКЛЮЧЕНИЕ}

Изучение зональности фенокристаллов плагиоклаза вулкана Кизимен, а также распределения содержаний макро- и микроэлементов в этих кристаллах позволяет сделать следующие выводы.

1. Все породы вулкана Кизимен, в том числе базальтовые и андезибазальтовые включения в них, являются гибридными и представляют собой результат смешения основного и кислого расплавов в различных пропорциях. Эти конечные члены, вероятно, являются дериватами одного или нескольких близких по составу первичных расплавов и формируются посредством фракционной кристаллизации при экстенсивном фракционировании амфибола.

2. Необычная негативная корреляция $\mathrm{MgO}$ и An в высоко-An плагиоклазах может объясняться нелинейным поведением коэффициента распределения $\mathrm{Kd}_{\mathrm{Mg}}$ в системе плагиоклаз-расплав.

3. Внедрение базальтовой магмы в приповерхностный дацитовый очаг вулкана Кизимен происходило эпизодически. При этом взаимодействие двух разных по составу и физическим характеристикам магм проявлялось комплексно: в то время как химическое смешение расплавов и кристаллов и последующая кристаллизация гибридного расплава широко развиты в породах вулкана, можно также наблюдать свидетельство переноса только тепла (или добавки воды), которое выражено в изменении содержания An компоненты в плагиоклазе при постоянных концентрациях в них малых элементов.

4. Корреляция увеличения основности андезибазальтовых и базальтовых включений с историей развития вулкана предполагает, что в настоящее время резервуары кислого и основного расплавов расположены в различных частях системы, при этом можно полагать, что внедрение базальтовой магмы в дацитовый резервуар является спусковым крючком извержений.

Авторы благодарны А.Д. Бабанскому, Д. Гарднеру, Б.Н. Гордейчику, А.П. Хренову и Е.В. Шаркову за конструктивные предложения, которые помогли улучшить рукопись.

Работа была поддержана проектом DFG Wo362/15-1+2, грантом № 00-0504000 кооперативной программы РФФИ-DFG, грантом № 08-
05-00600 РФФИ и грантами № 43.700.11.0005, № 43.043.11.1606 и № 01.700.12.0028 Федерального агентства по науке и инновациям.

\section{СПИСОК ЛИТЕРАТУРЫ}

Волынец О.Н., Пополитов Э.И., Флеров Г.Б., Кирсанов И.Т. Состав и геохимические особенности плагиоклазов четвертичных вулканических пород Камчатки и Курильских островов // Геохимия. 1977. № 5. С. 736-747.

Волынеи О.Н., Хренов А.П., Флеров Г.Б. и др. О месте и времени кристаллизации вкрапленников плагиоклаза эффузивов по данным изучения продуктов современных извержений вулканов Курило-Камчатской зоны // Вулканология и сейсмология. 1979. № 4. С. 34-48.

Иванов Б. В., Кадик А.А., Максимов А.П. Физико-химические условия кристаллизации андезитов Ключевской группы вулканов (Камчатка) // Геохимия. 1978. № 8. С. 1139-1156.

Иванов Б.В. Андезиты Камчатки. Справочник химических анализов вулканитов и основных породообразующих минералов. М.: Наука, 2008. 470 с.

Кадик А.А., Максимов А.П., Иванов Б.В. Физико-химические условия кристаллизации и генезис андезитов (на примере Ключевской группы вулканов). М: Наука, 1986. $157 \mathrm{c.}$

Мелекесцев И.В., Пономарева В.В, Волынеи О.Н. Вулкан Кизимен (Камчатка) - будущий Сент-Хеленс? // Вулканология и сейсмология. 1992. № 4. С. 3-32.

Наумов В.Б., Коваленко В.И., Бабанский А.Д., Толс$m ы x$ M.Л. Генезис андезитов по данным изучения расплавных включений в минералах // Петрология. 1997. T. 5. № 6. С. 654-665.

Плечов П.Ю., Фомин И.С., Мельник О.Э., Горохова Н.В. Эволюция состава расплава при внедрении базальтов в кислый магматический очаг // Вестник МГУ. Cep. IV. Геология. 2008. № 4. С. 247-257.

Пономарева В.В., Чурикова Т.Г., Мелекесцев И.В. и др. Позднеплейстоцен-голоценовый вулканизм Камчатки / Под ред. Лаверова Н.П. и др. Изменение окружающей среды и климата: природные и связанные с ними техногенные катастрофы. Т. 2. Новейший вулканизм северной Евразии: закономерности развития, вулканическая опасность, связь с глубинными процессами и изменениями природной среды и климата. М.: ИГЕМ РАН, ИФЗ РАН, 2008. С. 19-40.

Фрих-Хар Д.И. Кристаллизация магматического стекла и некоторые вопросы петрогенезиса. М.: Наука, 1977. $119 \mathrm{c}$.

Чурикова Т., Дорендорф Ф., Вёрнер Г. Природа геохимической зональности вкрест простирания Камчатской островной дуги / Под ред. Иванова Б.В. и др. Геодинамика и вулканизм Курило-Камчатской островодужной системы. Петропавловск-Камчатский: ИВГиГ ДВО РАН, 2001. С. 173-190.

Чурикова Т.Г., Иванов Б.В., Айкельбергер Дж. и др. Малые и редкие элементы в плагиоклазе - ключ к изучению процессов в магматическом очаге (на примере вулкана Кизимен, Камчатка) // Вулканизм и геодинамика: Материалы II Всероссийского симпозиума по вулканологии и палеовулканологии. Екатеринбург: Институт геологии и геохимии УрО РАН, 2003. С. 446-451.

Чурикова Т.Г., Соколов С.Ю. Магматическая эволюция вулкана Плоские Сопки, Камчатка (анализ изо- 
топной геохимии стронция) // Геохимия. 1993. № 10. C. 1439-1448.

Allègre C.J., Provost A., Jaupart C. Oscillatory zoning: a pathological case of crystal growth // Nature. 1981. V. 294. P. 223-228.

Ariskin A.A., Barmina G.S., Frenkel M.Ya., Nielsen R.L. COMAGMAT: a Fortran program to model magma differentiation processes // Computers and Geosciences. 1993. V. 19. P. $1155-1170$.

Bindeman I.N., Davis A.M., Drake M.J. Ion microprobe study of plagioclase-basalt partition experiments at natural concentration level of trace elements // Geochim. et Cosmochim. Acta. 1998. V. 62. № 7. P. 1175-1193.

Brophy J.G., Dorais M.J., Donnelly-Nolan J., Singer B.S. A textural and compositional (ion-probe and electron probe) study of plagioclase zonation styles in hornblende gabbro cumulates from Little Glass Mountain, Medicine Lake volcano, California: Implications for fractional crystallization mechanisms in calc-alkaline magma genesis // Contributions to Mineralogy and Petrology. 1996. V. 126. P. 121-136. Browne B., Izbekov P., Eichelberger J., Churikova T. Preeruptive storage conditions of the Holocene dacite erupted from Kizimen Volcano, Kamchatka // International Geology Review. 2010. V. 52. № 1. P. 95-110.

Browne B.L., Eichelberger J.C., Patino L.C. et al. Magma mingling as indicated by texture and $\mathrm{Sr} / \mathrm{Ba}$ ratios of plagioclase phenocrysts from Unzen volcano, SW Japan // J. of Volcanology and Geothermal Research. 2006. V. 154. P. 103-116.

Bunsen $R$. Über die Prozesse der volkanischen Gesteinbildungen Islands // Ann. Phys. Chem. 1851. № 83. P. 197-272.

Churikova T., Dorendorf F., Wörner $G$. Sources and fluids in the mantle wedge below Kamchatka, evidence from acrossarc geochemical variation // J. of Petrology. 2001. V. 42. № 8. P. 1567-1593.

Churikova T., Wörner G., Eichelberger J., Ivanov B. Minorand trace element zoning in plagioclase from Kizimen volcano, Kamchatka: insights on the magma chamber processes // Volcanism and subduction: the Kamchatka region. Geophysical Monograph Series / Eds Eichelberger J. et al. V. 172. Washington, DC: American Geophysical Union, 2007. P. 303-324.

Couch S., Sparks R.S.J., Carroll M.R. Mineral disequilibrium in lavas explained by convective self-mixing in open magma chambers // Nature. 2001. V. 411. P. 1037-1039.

Davidson J.P., Tepley III F.J. Recharge in volcanic system: evidence from isotope profiles of phenocrysts // Science. 1997. V. 275. P. 826-829.

Dorendorf F., Churikova T., Koloskov A., Wörner G. Late Pleistocene to Holocene activity at Bakening volcano and surrounding monogenetic centers (Kamchatka): volcanic geology and geochemical evolution // J. of Volcanology and Geothermal Research. 2000a. V. 104. P. 131-151.

Dorendorf F., Wiechert U., Wörner G. Hydrated sub-arc mantle: a source for the Kluchevskoy volcano, Kamchatka/Russia // Earth and Planetary Science Letters. $2000 \mathrm{~b}$. V. 175. P. 69-86.

Dungan M.A., Rhodes M.J. Residualg lassesa nd melt inclusions in basalts from DSDP legs 45 and 46:. Evidence for magma mixing // Contributions to Mineralogy and Petrology. 1978. V. 67. P. 417-431.

Eichelberger J.C. Andesitic volcanism and crustal evolution // Nature. 1978. V. 275. P. 21-27.
Eichelberger J.C., Chertkoff D.G., Dreher S.T., Nye C.J. Magmas in collision: rethinking chemical zonation in silicic magmas // Geology. 2000. V. 28. № 7. P. 603-606.

Eichelberger J.C., Izbekov P.E., Browne, B.L. Bulk chemical trends at arc volcanoes are not liquid lines of descent // Lithos. 2006. V. 87. P. 135-154.

Ginibre C., Kronz A., Wörner G. High-resolution quantitative imaging of plagioclase composition using accumulated back-scattered electron images: new constraints on oscillatory zoning // Contributions to Mineralogy and Petrology. 2002a. V. 142. P. 436-448.

Ginibre C., Wörner G., Kronz A. Minor- and trace-element zoning in plagioclase: implications for magma chamber processes at Parinacota volcano, northern Chile // Contributions to Mineralogy and Petrology. 2002b. V. 143. P. 300-315. Grove T.L., Baker M.B., Kinzler R.J. Coupled CaAl-NaSi diffusion in plagioclase feldspar: Experiments and application to cooling rate speedometry // Geochim. et Cosmochim. Acta. 1984. V. 48. P. 2113-2121.

Kawamoto $T$. Dusty and honeycomb plagioclase: indicators of processes in the Uchino stratified magma chamber, Izu Peninsula, Japan // J. Volcanol. Geotherm. Res. 1992. V. 49. P. 191-208.

Marsh B.D. Magma chambers // Annual Review of Earth and Planetary Sciences. 1989. V. 17. P. 439-474.

McNeill A.W., Danyushevsky L.V. Composition and crystallization temperatures of primary melts from hole $896 \mathrm{~A}$ basalts: evidence from melt inclusion studies // Proceedings of the Ocean Drilling Program. Scientific Results. 1996. V. 148. P. 21-35.

Sato $H$. Mg-Fe partitioning between plagioclase and liquid in basalts of Hole 504B, ODP Leg 111: a study of melting at $1 \mathrm{~atm} / /$ Proceedings of the Ocean Drilling Program. Scientific Results. 1989. V. 111. P. 17-26.

Severs M.J., Beard J.S., Fedele L. et al. Partitioning behavior of trace elements between dacitic melt and plagioclase, orthopyroxene, and clinopyroxene based on laser ablation ICPMS analysis of silicate melt inclusions // Geochim. et Cosmochim. Acta. 2009. V. 73. P. 2123-2141.

Stormer J.C. The effects of recalculation on estimates of temperature and oxygen fugacity from analyses of multicomponent iron-titanium oxides // American Mineralogist. 1983. V. 68. № 5-6. P. 586-594.

Sun S.-S., McDonough W.F. Chemical and isotopic systematics of oceanic basalts: implications for mantle composition and processes // Magmatism in the ocean basins. Geological Society Special Publications Eds Saunders A.D., Norry M.J. Geological Society of London. 1989. № 42. P. 313-345.

Tepley III F.J., Davidson J.P., Tilling R.I., Arth J.G. Magma mixing, recharge and eruption histories recorded in plagioclase phenocrysts from El Chichón Volcano, Mexico // J. of Petrology. 2000. V. 41. № 9. P. 1397-1411.

Todt W., Cliff R.A., Hanser A., Hofmann A.W. ${ }^{202} \mathrm{~Pb}-{ }^{205} \mathrm{~Pb}$ spike for $\mathrm{Pb}$ isotope analysis // Terra Cognita. 1984. V. 4. P. 209.

Tsuchiyama A. Dissolution kinetics of plagioclase in the melt of the system diopside-albite-anorthite, and origin of dusty plagioclase in andesites // Contrib. Mineral. Petrol. 1985. V. 89. P. 1-16.

Winter J.D. An introduction to igneous and metamorphic petrology. New Jersey: Prentice-Hall Inc., 2001. 697 p. 


\title{
Major and Trace Element Zoning in Plagioclase from Kizimen Volcano (Kamchatka): Insights into Magma-Chamber Processes
}

\author{
T. G. Churikova ${ }^{a, b}$, B. V. Ivanov ${ }^{a}$, J. Eichelberger ${ }^{c}$, G. Voerner $^{b}$, B. Browne ${ }^{d}$, and P. Izbekov \\ ${ }^{a}$ Institute of Volcanology and Seismology, Far East Branch, Russian Academy of Sciences, \\ Piipa bul'var, 9, Petropavlovsk-Kamchatskii, 683006 Russia \\ e-mail: tchuricova@mail.ru \\ ${ }^{b}$ Geochemistry Division, Center of Geological Sciences, Goettingen University, \\ Goldschmidt Str., 1, Goettingen, 37077 Germany \\ e-mail: gwoerne@gwdg.de \\ ${ }^{c}$ Volcanic Hazards Program, USGS, Reston, Virginia, United States \\ e-mail: jeichelberger@usgs.gov \\ ${ }^{d}$ Geological Sciences Department, California State University, Fullerton, California, United States \\ e-mail: bbrowne@fullerton.edu \\ ${ }^{e}$ Volcano Observatory, Geophysical Institute of the University of Alaska, Fairbanks, Alaska, United States \\ e-mail:pavel@gi.alaska.edu
}

\begin{abstract}
The data on the geochemistry of the rocks of Kizimen Volcano and results of microprobe studies of major and trace elements in plagioclase grains from acid lavas and basalt inclusions are presented. The characteristics of the Kizimen Volcano are the following: (1) basalt inclusions are abundant in acid lavas; (2) banded, mixed lavas occur; (3) the distribution curves of rare-earth elements of acidic lavas and basalt inclusions intersect; (4) $\mathrm{Sr}-\mathrm{Nd}$ isotope systematics of the rocks and inclusions do not indicate mixture with crustal material; (5) plagioclase phenocrysts are of direct and reverse zonality; (6) olivine and hornblende, as well as acid and basic plagioclases, coexist in the rocks. The studies revealed that the rocks are of a hybrid nature and originated in the course of repeated mixture of acid and basic melts either with chemical and thermal interaction of melts or exclusively thermal ones. Study of the major- and trace-element distribution in zonal minerals provides an informative to
\end{abstract}

